\title{
ТЕХНИКО-ТЕХНОЛОГИЧЕСКИЕ
}

ИННОВАЦИИ

DOI: http://dx.doi.org/10.15688/jvolsu10.2015.3.3

УДК 661.183 .55

ББК 28.072

\section{WIDE-PORE CRYOGELS PREPARED USING THE COMBINATION OF LIQUID-LIQUID PHASE SEPARATION AND CRYOTROPIC GEL-FORMATION PROCESSES}

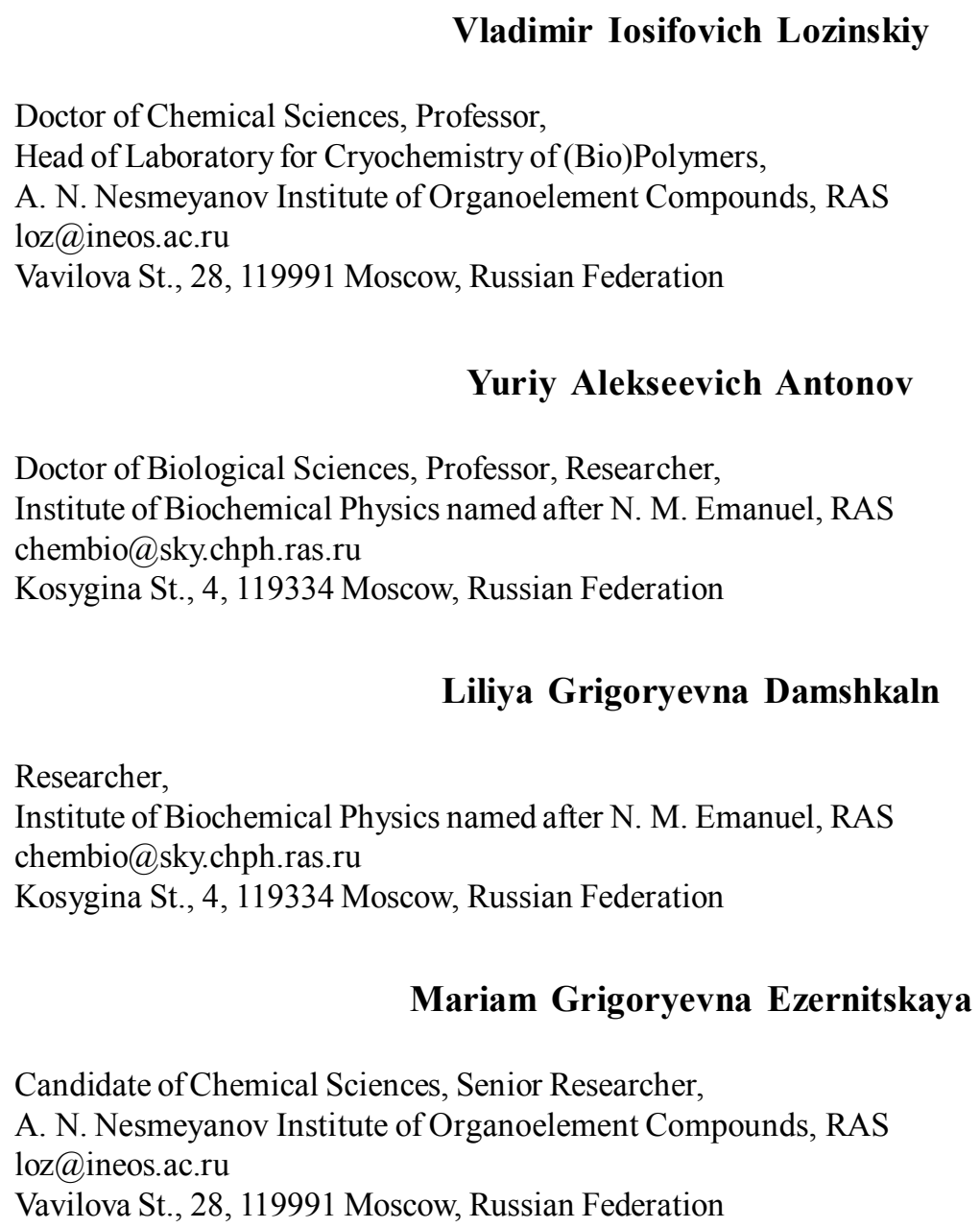

Yuriy Alekseevich Antonov

Doctor of Biological Sciences, Professor, Researcher, Institute of Biochemical Physics named after N. M. Emanuel, RAS chembio@sky.chph.ras.ru Kosygina St., 4, 119334 Moscow, Russian Federation

\section{Liliya Grigoryevna Damshkaln}

Researcher, Institute of Biochemical Physics named after N. M. Emanuel, RAS chembio@sky.chph.ras.ru Kosygina St., 4, 119334 Moscow, Russian Federation

Mariam Grigoryevna Ezernitskaya

Candidate of Chemical Sciences, Senior Researcher, A. N. Nesmeyanov Institute of Organoelement Compounds, RAS loz@ineos.ac.ru Vavilova St., 28, 119991 Moscow, Russian Federation 


\title{
Yuliya Konstantinovna Glotova
}

\author{
Researcher, \\ Institute of Biochemical Physics named after N. M. Emanuel, RAS \\ chembio@sky.chph.ras.ru \\ Kosygina St., 4, 119334 Moscow, Russian Federation
}

\begin{abstract}
Novel, previously unknown, wide pore poly(vinyl alcohol) cryogels (PVACGs) have been prepared through the cryotropic gelation approach, when water-PVA-gum Arabic (GuAr) ternary liquid systems were used as feeds. The following set of conditions necessary for obtaining wide-porous, permeable for a water flow, and, simultaneously, mechanically strong enough PVACGs was established: the total concentration of gelling component - PVA (MW of $86 \mathrm{kDa}$ ) and non-gelling polymer - GuAr (MW of $\sim 650 \mathrm{kDa}$ ) should exceed $\sim 14 \mathrm{wt} . \%$, GuAr/PVA ratio should be near $1: 1(\mathrm{w} / \mathrm{w})$, and the feed's $\mathrm{pH}$ should be within the range of $\sim 5-11$. The phase diagrams for the water-PVA-GuAr ternary liquid systems at $\mathrm{pH} 5.3$ and 10.0 have demonstrated that such "optimum" compositions are in the vicinity of the rectilinear diameters of the respective diagrams, and that the limit of GuAr solubility in the PVA-rich phase is small. In such cases this GuAr fraction strongly binds with PVA, especially under alkaline conditions, within the forming gel phase of heterophase PVACG. The light microscopy studies revealed the presence of at least three distinct kinds of pores in these cryogels. Firstly, there are interconnected channel-like gross pores with cross-section of 100-200 $\mu \mathrm{m}$ which are the replicas of continuous GuAr-rich phase in the two-phase polymeric systems appearing due to the liquid-liquid phase separation in the ternary water-PVA-GuAr system. The second type is represented by isolated roundish large pores ca. 10-70 $\mu \mathrm{m}$ in diameter being the replicas of GuAr-rich phase dispersed as liquid droplets in the PVA-rich phase. And the third type is represented by the smaller rounded pores $\sim 1-5 \mu \mathrm{m}$ in diameter being the replicas of ice polycrystals. Such sophisticated "poly-porous" morphology of the studied PVA cryogels is their unique feature distinguishing them from other known PVA cryogels.
\end{abstract}

Key words: poly(vinyl alcohol), gum Arabic, liquid-liquid phase separation, freezingthawing, wide pore cryogels.

\section{INTRODUCTION}

Poly(vinyl alcohol) cryogels (PVACGs) are physical (non-covalent) macroporous gels formed as a result of freeze-thaw processing of concentrated solutions of the polymer [40-42; 52; 56]. On the one hand, these gel materials have excellent physical properties, namely, high gel strength and, simultaneously, high reversible deformability - plasticity, relatively high heat endurance, low abrasive erosion upon intense stirring, for instance, the beaded PVACGs, etc. On the other hand, a distinctive feature of PVA cryogels is their macroporosity, i.e. they have a system of interconnected pores with cross-section up to several micrometers.

Since their discovery, PVA cryogels have attracted attention in diverse applied areas, especially in the field of biomaterials (gels for controlled drug release, covers for wounds and burns, artificial cartilages, components of model heart implants and artificial blood vessels, phantoms for calibrating NMR tomographs and ultrasound equipment, etc.) $[29 ; 40-42 ; 52 ; 56$; $74]$ and in biotechnology (carriers of immobilized enzymes and cells, matrices for immunosorbents, etc.) $[40-42 ; 49 ; 73]$. This attention is largely conditioned by the combination of high gel strength and macroporosity. Their large pores appear upon melting of the solvent crystals (ice in the case of aqueous systems), so these crystals act as porogens in the course of PVA cryotropic gelformation $[41 ; 42 ; 45 ; 69 ; 70 ; 76 ; 80]$ and microcrystallites stabilized by the intermolecular hydrogen bonds between the neighbouring $\mathrm{OH}-$ groups of different chains form interchain links (junction knots of the 3D supramolecular network) $[19 ; 20 ; 41 ; 60 ; 61 ; 72 ; 80]$. 
Along with simple aqueous or DMSO solutions of the polymer for producing PVACGs, numerous researchers used initial feeds containing diverse low and/or high molecular solutes, e.g., salts, sugars, mono- or poly-hydroxyl alcohols, amino acids, various pharmaceutics, synthetic polymers or natural biopolymers (polysaccharides, proteins, nucleic acids). Such additives were shown to affect the properties and porous structure of the respective PVA cryogels $[7 ; 8 ; 11 ; 15 ; 20 ; 41 ; 42 ; 56 ; 68]$. Among such systems those composed of the solvent (water), PVA and some polymeric additives are of special interest because of the possibility to meet the exhibition of the effects of thermodynamic incompatibility of the polymeric components. In such a case, two extreme scenarios can occur:

(i) the initial common solution of PVA and the second polymer undergoes liquid-liquid de-mixing (the behaviour inherent in the well-known Albertsson's liquid two-phase polymeric systems [1]) yet prior to the cryogenic treatment, so the already formed two mixed coexisting liquids are frozen;

(ii) the initial solution of PVA and the second polymer is frozen while being still a monophase liquid, and, since pure ice is initially crystallized, both polymeric components are concentrated in the so-called unfrozen liquid microphase (ULMP) [42; 63], and such cryo-concentrating process causes the liquid-liquid phase separation within the volume of such ULMP.

Intermediate cases are certainly possible, since the phase segregation in viscous polymeric solutions can be relatively slow, i.e. the process is controlled kinetically.

These features of PVA freeze-thaw gelation in the systems containing water, PVA and an additional macromolecular solute have not been, in fact, so far studied systematically, except for several empiric observations. Therefore, the goal of our research was to reveal how the combination of liquid-liquid phase separation and cryotropic gel-formation affects the physical and chemical properties and macroporosity of the resulting PVACGs, as well as to find means to control these characteristics of such PVA cryogels. In a view of such aims the studies were performed for the system water-PVA-gum Arabic. This system has been chosen because the aqueous solutions of the second polymer, i.e. gum Arabic (GuAr), per se do not form cryogels after freezing - storing frozen - thawing.

\section{EXPERIMENTAL}

\subsection{Materials}

PVA(lot \#A0265775) with molecular weight of $86 \mathrm{kDa}$ and deacetylation degree (DD) of 99$100 \%$, as well as GuAr (lot \#A004085701) (both from Acros Organics; Ceel, Belgium), were used without additional purification. The average molecular weight of gum Arabic determined by the static light scattering in $0.15 \mathrm{M} \mathrm{NaCl}$ medium [3] was found to be $650 \mathrm{kDa}$. The Congo red dye (Aldrich Chemical Co., USA), gelatine (photo quality), phenol (pure for analysis), glycerol (pure for analysis) (all Reakhim Co., Russian Federation) were employed as received. All aqueous solutions were prepared using deionized water.

\subsection{Methods \\ 2.2.1. Initial polymeric solutions for the preparation of cryogels \\ PVA stock solutions $(15 \% \mathrm{w} / \mathrm{w})$ were made} as follows. The calculated amount of PVA was suspended in the required volume of water; the mixture was stored for $15 \mathrm{~h}$ at room temperature for the polymer to swell. Then the suspension was heated for $1 \mathrm{~h}$ under stirring in a boiling water bath for complete PVA dissolution. The sample was weighed before and after heating, and the amount of evaporated water was compensated. GuAr stock solutions $(20 \% \mathrm{w} / \mathrm{w})$ were prepared by suspending weighed amount of the polymer in known volume of water followed by heating the mixture at $70-80{ }^{\circ} \mathrm{C}$ under stirring until complete $\mathrm{GuAr}$ dissolution. The loss of evaporated water was compensated. The obtained polymeric solutions were filtered through a nylon mesh and then used while warm $\left(35-45^{\circ} \mathrm{C}\right)$ for making the mixed liquid systems to be cryogenically processed. The $\mathrm{pH}$-values of the initial feeds were, when required, adjusted to the desired levels by adding the aliquots of $0.5 \mathrm{~N} \mathrm{NaOH}$ solution.

\subsubsection{Phase diagrams of the systems} water-PVA-GuAr

Solutions of PVA and GuAr were prepared as indicated in section 2.2.1. The resulting solutions were centrifuged at $60.000 \times \mathrm{g}$ with a Beckman J2-21 centrifuge (Beckman Coulter, Inc., USA) for $1 \mathrm{~h}$ at $23^{\circ} \mathrm{C}$ to remove possible insoluble admixtures. Concentrations of the solutions were determined by drying weighed samples at $100{ }^{\circ} \mathrm{C}$ up to constant weight. The 
ternary water-PVA-GuAr systems of required compositions were prepared by mixing solutions of each polymer. After mixing for $1 \mathrm{~h}$, the systems were centrifuged at $60.000 \times g$ for $1 \mathrm{~h}$ at $23{ }^{\circ} \mathrm{C}$ to separate the coexisting phases.

The phase diagrams of the ternary systems were obtained at $\mathrm{pH} 5.3$ (the mixtures of PVA and $\mathrm{GuAr}$ solutions without $\mathrm{pH}$ adjusting) and at $\mathrm{pH}$ 10. The scheme of the diagram creation is illustrated by Fig. 1, $a$ and $b$; the procedure was adapted from Koningsveld \& Staverman [28] and Polyakov et al. [59]. The separately prepared GuAr and PVA solutions (concentrations $C^{\mathrm{o}}{ }_{2}$ and $\mathrm{C}_{3}^{\mathrm{o}}$, respectively) were mixed at $23{ }^{\circ} \mathrm{C}$ in various weight ratios, yielding mixtures with concentrations of these polymers $C_{2}$ and $C_{3}$, respectively, which are represented in the phase diagram by the secant $\left[\mathrm{C}_{2}^{\mathrm{o}}, \mathrm{C}_{3}^{\mathrm{o}}\right]$. The phase state of the systems was determined visually after centrifugation following a rest period of $1 \mathrm{~h}$ at $23^{\circ} \mathrm{C}$. When phase separation occurred, the volumes of the two coexisting liquid phases were measured. The points where the bimodal intersects the secant $\left[\mathrm{C}_{2}^{\mathrm{o}}, \mathrm{C}_{3}^{\mathrm{o}}\right]$ are given by extrapolation of the relation:

$$
r=V^{\prime}\left(V^{\prime}+V^{\prime \prime}\right)=f\left(C_{2} / C_{2}^{o}\right) \text { to } r=0 \text { and } 1
$$

where $V^{\prime}$ and $V^{\prime \prime}$ represent volumes of the GuAr-enriched and the PVA-enriched phases, respectively. The value $r=0.5$ gives the position of the middle of the tie lines. By repeating this procedure for a series of values of $C^{\circ}{ }_{2}$ and $C_{3}^{\circ}$, the phase diagram can be reconstructed from the set of points corresponding to the binodal and the centre of the tie lines.

The phase composition of the separated systems was derived from both the material balance of the

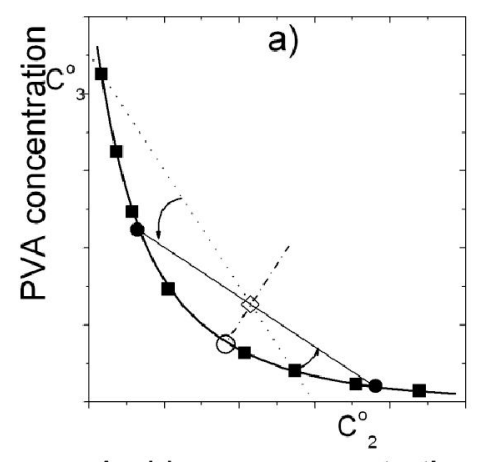

Arabic gum concentration systems studied and the position of the binodal in the plot, using the ratio [1]:

$$
\frac{V^{\prime \prime}}{V^{\prime}}=\frac{\rho^{\prime} X}{\rho^{\prime \prime} Y}
$$

where $V^{\prime \prime}$ and $V^{\prime}$ are the volumes, $\rho^{\prime \prime}$ and $\rho^{\prime}$ are the densities of the GuAr-enriched and PVA-enriched phases, respectively; $X$ and $Y$ are the distances in the plot between the points corresponding to (i) the composition of GuAr-enriched phase and the composition of the initial mixture $(X)$, and (ii) the composition of PVA-enriched phase and the composition of the initial mixture $(Y)$.

The phase composition of the separated systems was checked on the basis of the system's material balance. The compatibility of PVA and GuAr was characterized by the coordinates of the threshold $\left(C_{\mathrm{PVA}}{ }^{*} ; C_{\mathrm{GuAr}}{ }^{*}\right)$, and critical $\left(C_{\mathrm{PVA}}{ }^{\text {cr }}\right.$, $C_{\mathrm{GuAr}}{ }^{\mathrm{cr}}$ ) points, the ratio of the molal concentrations of PVA and GuAr in the critical point, characterizing symmetry of the phase diagram $\left(K_{s}^{m}=m_{\mathrm{PVA}}{ }^{\mathrm{cr}} / m_{\mathrm{GuAr}}{ }^{\mathrm{cr}}\right)$ [3] as well as by the values of maximum solubility of PVA in a concentrated solution of $\mathrm{GuAr}-C_{\mathrm{PVA}}$ lim, and maximum solubility of GuAr in a concentrated solution of PVA $-C_{\mathrm{GuAr}} \lim$ (limit of solubility). The threshold point was determined as the point where the line with the slope of - 1 is the tangent to the binodal. The total concentration of PVA and $\mathrm{GuAr}$ in this point $\left(C_{t}^{*}\right)$ is the minimal total concentration of the biopolymers at which the system undergoes phase separation. The critical point of the system was defined as the point where the binodal intersects the rectilinear diameter, which is the line joining the centre of the tie lines (Fig. 1).

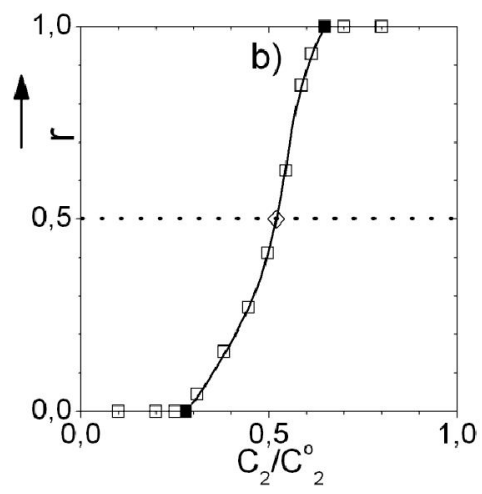

Fig. 1. Schematic illustration of the phase volume ratio method:

$a$ - fragment of the phase diagram (dash-dotted line - secant, thick full line - binodal, thin full line - tie line, dotted line - rectilinear diameter, $\bullet$ - phase composition, - - points of the binodal, o - critical point); $b$ - typical dependence of the phase volume ratio on mixture composition 


\subsubsection{Cryogenic structuring}

For the preparation of PVACG, $3 \mathrm{~mL}$ of each mixed liquid feed was sucked into a plastic 5-mL-syringe, sealed and placed in the chamber of precision programmable cryostat $\mathrm{F} 32 \mathrm{ME}$ (Julabo, Germany), where the sample was frozen at $-30{ }^{\circ} \mathrm{C}$ for $30 \mathrm{~min}$, further kept frozen at $-5^{\circ} \mathrm{C}$ for $12 \mathrm{~h}$ and then thawed at the rate of $0.03{ }^{\circ} \mathrm{C} /$ min controlled by the cryostat microprocessor. After defrosting the wide pore cylindrical PVACG thus prepared was rinsed with deionised water by passing $300 \mathrm{~mL}$ of water (or a $\mathrm{NaOH}$ solution, see below) through the syringe at constant hydrostatic pressure equal to $100 \mathrm{~cm}$ of watercolumn.

\subsubsection{Hydrodynamic properties of wide- pore PVACG columns}

The water flow rates $(\mathrm{mL} / \mathrm{h})$ through the PVACG-containing syringes were determined under the same conditions as those employed for rinsing such cylindrical cryogels. The experiments were carried out at $22 \pm 1{ }^{\circ} \mathrm{C}$ using five parallel samples; the results obtained were averaged.

\subsubsection{Gel strength}

The compression of Young's modulus $(E)$ of the cryogel samples was determined from the linear portion of the stress-strain dependence measured using a TA-Plus automatic texture analyzer (Lloyd Instruments, Great Britain) at a loading rate of $0.3 \mathrm{~mm} / \mathrm{min}$. Measurements were performed until $30 \%$ deformation extent for the PVACGs formed inside the syringes. The samples were cut with a razor as cylinders of $12 \mathrm{~mm}$ in height, and each cryogel sample was laid down on a flank, so the load was applied in the direction normal to the cylinder axis (Fig. 2).

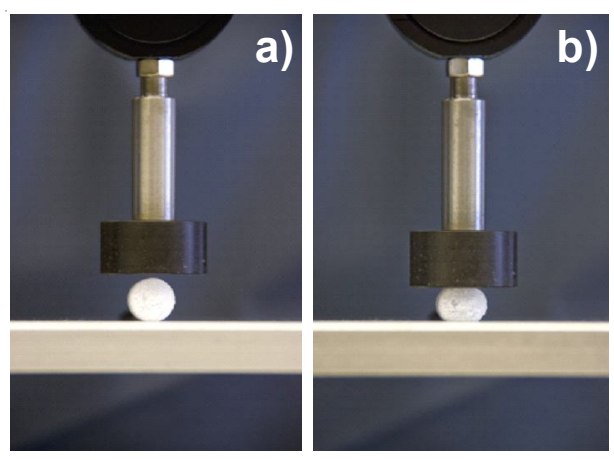

Fig. 2. The photographs of the intact $(a)$ and deformed $(b)$ wide pore PVACG sample in the measuring cell of a TA-Plus texture analyzer

\subsubsection{Fusion temperature of PVACG} samples

Gel fusion temperatures $\left(T_{\mathrm{f}}\right)$ were determined as follows. The syringes (with closed outlets) containing rinsed PVACG-columns were used. Prior to measurement, a $\sim 5$-mm-depth incision was made with a small scalpel on the top of each spongy cryogel, and a stainless steel ball of $3.5 \mathrm{~mm}$ diameter and weight of $0.275 \pm 0.005 \mathrm{~g}$ was placed in the incision. The upper part of the syringe was sealed with a rubber stopper, whereupon the syringe was placed into a water bath. The bath temperature was increased at the rate of $0.4 \pm 0.1^{\circ} \mathrm{C} / \mathrm{min}$. The gel fusion point was determined as the temperature when the ball fell down to the bottom of the syringe after passing through the fused PVACG.

\subsubsection{FTIR spectra of the polymeric samples}

Spongy cryogel formed inside the syringe was first rinsed from the sol-fraction in a flowthrough mode, afterwards the cylindrical sample was placed in the test tube, corked and heated on a boiling water bath to fuse the gel. Viscous polymer solution thus obtained was cast as a layer of about 1-mm-thickness in a plastic Petri dish and kept open at room temperature for the film formation. Finally, the film was dried in vacuum dessicator over the burned $\mathrm{CaCl}_{2}$ granules. FTIR spectra of the films thus prepared were recorded on a Magna-IR 750 Fourier spectrometer (Nicolet, France) with a resolution of $2 \mathrm{~cm}^{-1}$.

\subsubsection{Porous morphology of PVACGs}

The morphology of cryogel samples was studied using optical microscope Eclipse 55i (Nikon, Japan) equipped with a system for digitally recording images. For this end the PVACGs were moulded either (i) as cylindrical samples inside the syringes, or (ii) as platelike shaped discs. Further, thin $(\sim 10 \mu \mathrm{m})$ sections of PVACG cylinder (i) parallel to the sample axis (longitudinal section) were prepared with a SM-1900 cryomicrotome (Leica, Germany). Then, each section was put into distilled water and submerged for 10 seconds into the $1 \%(\mathrm{w} / \mathrm{w})$ Congo red aqueous solution for staining. The excess of dye was rinsed off with water, the section was placed onto a microscope glass; excessive water was removed with a gauze tampon and one drop of "fixing medium" (solution of $1 \mathrm{~g}$ of gelatine in $12 \mathrm{ml}$ of $50 \%$ aqueous glycerol and $0.2 \mathrm{~g}$ of phenol as a bactereostatic agent) and sealed with a cover glass. Prior to studies the samples were stored at $4{ }^{\circ} \mathrm{C}$ in a closed vessel. In 
case (ii), a 2-mm-layer of polymer solution was poured into a plastic Petri dish (36 mm inner diameter), which was quickly installed in a flat pallet immersed in the coolant of the cryostat to freeze the system of interest. After the process completion, the gel sample thus prepared was rinsed 10 times with an excess of deionised water and stained by submersion in $1 \%$ aqueous Congo red solution for 20 seconds followed by exhaustive rinsing with water.

The values of the Young's moduli and water flow rates through the PVACG columns were measured for 4 parallel samples; the samples were obtained in 3-5 independent experiments (this also relates to morphological studies). The results obtained were averaged.

\section{RESULTS AND DISCUSSION}

\subsection{Phase States of the Water-PVA- GuAr Systems}

It was earlier established $[32 ; 41 ; 45]$ that rigid enough PVACGs can be prepared on the basis of PVA with MW $\sim 80-100 \mathrm{kDa}$ and DD $\sim 100 \%$, when the polymer concentration in the initial feed is not less than $40-50 \mathrm{~g} / \mathrm{L}$. Therefore, during the preliminary evaluating experiments within this study we used mixed aqueous polymeric solutions that contained the gel-forming precursor, i.e. PVA, in amount as high as $50 \mathrm{~g} / \mathrm{L}$. The second macromolecular component, i.e. GuAr, the complex poly(peptidoglucane), consists of the proteinaceous core chain with pendant branched carbohydrate blocks [77]. The latter include noncharged monosaccharide units (galactose, arabinose and rhamnose), as well as carboxylic monosaccharides - glucuronic acid and 4-O-methyl glucuronic acid. Owing to such a branched bulky structure of the macromolecules and the presence of charged groups, GuAr is capable of binding huge amount of water upon solvation, so in the mixed solutions of GuAr with another dissolved polymer a rather strong competition for water should occur thus facilitating liquid-liquid phase segregation. Taking also in account the fact that aqueous GuAr solutions are not per se able to form physical cryogels upon freeze-thaw processing, we have selected GuAr as the non-gelling second polymer for the preparation of wide pore PVACGs. The idea was to use the dispersed GuAr-rich phase for creating very large pores in the bulk of PVA cryogel formed on the basis of PVA-rich phase. Therefore, we have, first of all, created ternary phase diagrams for the water-PVA-GuAr system and then determined boundary polymer concentrations necessary for preparing the respective PVACGs. The phase diagram of the water-PVA-GuAr system is shown in Fig. 3, and the principal parameters of phase diagrams obtained for the polymeric systems with $\mathrm{pH}$ values 5.3 and 10 (section 3.3) are listed in Tables 1 and 2.

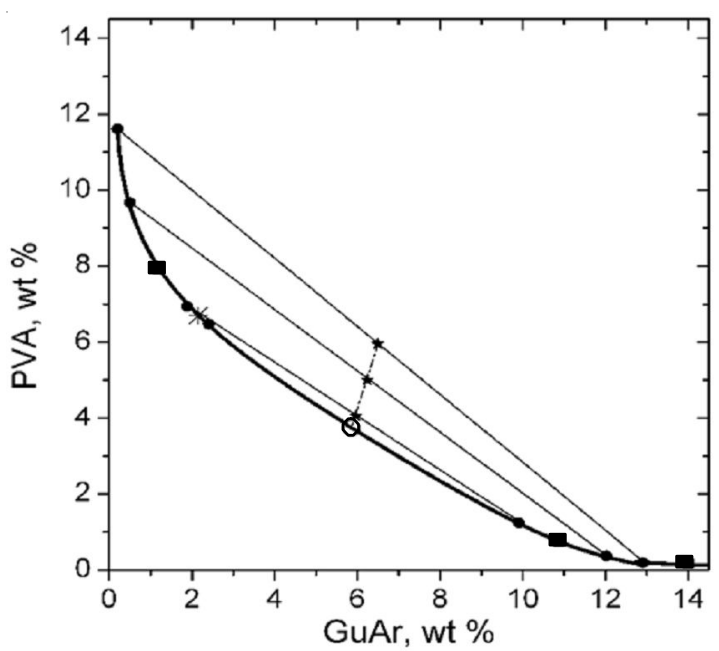

Fig. 3. Isothermal $\left(20^{\circ} \mathrm{C}\right)$ phase diagram of water-PVA-GuAr system at $\mathrm{pH}$ 5.3:

thick full line - binodal; thin full line - tie line; dotted line, rectilinear diameter; $\bullet-$ phase composition;

- points of the binodal; o - critical point; * - threshold point

Table 1

Coordinates of the critical points of the phase diagrams of the water-PVA-GuAr system and symmetry criterion in weight concentrations

\begin{tabular}{|c|c|c|c|c|c|c|c|}
\hline $\begin{array}{c}\mathrm{pH} \\
\text { of the system }\end{array}$ & $\begin{array}{l}C_{\mathrm{PVA}}{ }^{\mathrm{cr}}, \\
\text { wt. \% }\end{array}$ & $\begin{array}{l}C_{\text {GuAr }}{ }^{\mathrm{cr}} \text {, } \\
\text { wt. \% }\end{array}$ & $\begin{array}{c}C_{t}^{\mathrm{cr}}, \\
\text { wt. \% }\end{array}$ & $\begin{array}{c}10^{5} \mathrm{~m}_{\mathrm{PVA}}{ }^{\mathrm{cr}} \\
\mathrm{mol} / \mathrm{kg}\end{array}$ & $\begin{array}{c}10^{5} \mathrm{~m}_{\mathrm{GuAr}}^{\mathrm{cr}} \\
\mathrm{mol} / \mathrm{kg}\end{array}$ & $10^{5} \mathrm{M}_{t}^{\mathrm{cr}}$ & $K_{s}^{m}$ \\
\hline 5.3 & 3.74 & 5.85 & 9.60 & 4.348 & 0.9 & 5.25 & 4.83 \\
\hline 10 & 2.95 & 4.57 & 7.52 & 3.430 & 0.703 & 4.133 & 4.88 \\
\hline
\end{tabular}

Note. $C_{t}^{\mathrm{cr}}=C_{\mathrm{PVA}}{ }^{\mathrm{cr}}+C_{\mathrm{GuAr}}$. 
Threshold point $C_{\mathrm{t}}^{*}$ and its coordinates $\left(C_{\mathrm{PVA}}{ }^{*}\right.$ and $\left.C_{\mathrm{GuAr}}{ }^{*}\right)$, and limit of solubility of PVA in a concentrated solution of GuAr $\left(C_{\mathrm{PVA}}\right.$ lim $)$, and limit of solubility of $\mathrm{GuAr}$ in a concentrated solution of PVA $\left(C_{\mathrm{PVA}}{ }^{\mathrm{lim}}\right)$

\begin{tabular}{|c|c|c|c|c|c|}
\hline $\begin{array}{c}\mathrm{pH} \\
\text { of the system }\end{array}$ & $\begin{array}{c}C_{\mathrm{PVA}}^{*}, \\
\text { wt. \% }\end{array}$ & $\begin{array}{c}C_{\mathrm{GuAr}}{ }^{*}, \\
\text { wt. \% }\end{array}$ & $\begin{array}{c}C_{t}^{*}, \\
\text { wt. \% }\end{array}$ & $\begin{array}{c}C_{\mathrm{PVA}}{ }^{\lim }, \\
\text { wt. \% }\end{array}$ & $\begin{array}{c}C_{\mathrm{GuAr}}^{\lim } \\
\text { wt. \% }\end{array}$ \\
\hline 5.3 & 6.70 & 2.15 & 8.85 & 0.17 & 0.19 \\
\hline 10 & 4.27 & 2.96 & 7.21 & 0.10 & 0.10 \\
\hline
\end{tabular}

It was found that the total concentration of the polymers in the critical point $\left(C_{t}^{\text {cr }}\right)$ is $9.6 \mathrm{wt} . \%$, whereas the total concentration in the threshold point $\left(C_{t}^{*}\right)$ is only slightly less than $C_{t}^{\text {cr }}$ (8.85 wt. \%). These values are relatively high as compared to the same parameters of the aqueous polysaccharide- 1 - polysaccharide- 2 systems studied before $[1 ; 3]$. In other words, compatibility of the polymers is relatively high in the middle part of the phase diagram in case of a small excess of either polymer in the system. At the same time, both the limit of solubility [3] of PVA (0.17 wt. \%) in the concentrated solutions of GuAr and the limit of solubility of $\operatorname{GuAr}(0.19$ wt. \%) in the concentrated solutions of PVA are small. Thus, the compatibility of these polymers is low in case of significant excess of one polymeric component in the ternary system. The phase diagram obtained (Fig. 3) is asymmetric (the critical point expressed in molal concentrations corresponds to higher concentration of PVAthan $\operatorname{GuAr}\left(K_{s}^{m}=4.8\right)$, and weakly depends on $\mathrm{pH}$ ).

General theoretical concepts of the phase separation in ternary polymer-1 - polymer- 2 solvent systems conclude $[23 ; 81]$ that such a small asymmetry is the result of insignificant difference between the second virial coefficients characterizing the polymer-solvent interactions under given conditions. So, based on the phase diagram data (Fig. 3 and Table 1), it became evident that the second virial coefficient for PVA is less than that of GuAr. In other words, PVA is more hydrophobic polymer than GuAr (the same is also clear qualitatively from the chemical structure of the latter polymer bearing the ionogenic groups).

\subsection{Freeze-Thaw-Caused Gel-} Formation of the Systems Water-PVA-GuAr

It was found in the initial preparatory experiments that spongy PVACGs possessing high enough gel strength and permeable for water stream under the conditions used for evaluating the hydrodynamic characteristics of the cryogel-filled columns (syringes) were formed when the PVA content in the feed polymer solutions ranged from $\sim 60$ to $\sim 110 \mathrm{~g} \mid \mathrm{L}$ (i.e., around 6-11 wt. \%), and that of GuAr was 57-116 g|L (also around 6-11 wt. \%). With that the optimal conditions of the cryogenic process to obtain the desired porosity characteristics (wide-porous morphology) of respective cryogels were found to be the following: freezing at $-30{ }^{\circ} \mathrm{C}$ for $15 \mathrm{~min}$, then frozen storage at $-5{ }^{\circ} \mathrm{C}$ for $12 \mathrm{~h}$, and finally heating at the rate of $0.03{ }^{\circ} \mathrm{C} / \mathrm{min}$ to defrost the samples. Surprisingly, the "optimal" thermal regime for preparing wide pore spongy agarose-based cryogels, found previously [34], was the same. This coincidence could, of course, be rather fortuitous. Such temperature profile was further employed in this study for preparing spongelike PVACGs for all the initial polymeric compositions to be cryogenically structured. We used water flow rates (FR) through the respective columnar beds inside the syringes (see section 2.2.4) as the parameter characterizing cryogel macroporosity. Such flow-through rates, as it was earlier shown for the spongelike poly(acrylamide) [2;37; 58], agarose [34], and chitosan [53; 54] cryogels, are sensitive indicators of the macropore size, since FR values increase with the pore cross section due to the decrease in the flow resistance at equal hydrostatic pressure. The data in Table 3 demonstrate the influence of the total polymer concentration in the initial feed and GuAr/PVA ratio on the FR values for the series of PVACGs columns thus prepared, when the $\mathrm{pH}$ of the initials feeds 5.3 was not additionally adjusted.

The data in this table are arranged in three groups: 


\section{Hydrodynamic characteristics of PVACG-columns prepared from Water-PVA-GuAr feeds of various compositions}

\begin{tabular}{|c|c|c|c|c|c|}
\hline \multirow{2}{*}{$\begin{array}{c}\text { Example } \\
\text { number }\end{array}$} & $\begin{array}{c}\text { Total concentration } \\
\text { of the polymeric } \\
\text { components (wt. \%) }\end{array}$ & $\begin{array}{c}\text { GuAr concent- } \\
\text { ration in the feed } \\
\text { (wt. \%) }\end{array}$ & $\begin{array}{c}\text { PVA concent- } \\
\text { ration in the feed } \\
\text { (wt. \%) }\end{array}$ & $\begin{array}{c}\text { Weight } \\
\text { ratio } \\
\text { GuAr/PVA }\end{array}$ & \multirow{2}{*}{$\begin{array}{c}\text { FR } \\
\text { (mL/h) }\end{array}$} \\
\hline $1 a$ & 12.0 & 6.0 & 6.0 & $1: 1$ & ${ }^{\text {a) }}$ \\
\hline$b$ & 14.0 & 7.0 & 7.0 & $1: 1$ & ${ }^{\text {a) }}$ \\
\hline$c$ & 16.0 & 8.0 & 8.0 & $1: 1$ & $231.8 \pm 8.7$ \\
\hline$d$ & 18.0 & 9.0 & 9.0 & $1: 1$ & $240.3 \pm 5.8$ \\
\hline$e$ & 20.0 & 10.0 & 10.0 & $1: 1$ & $226.7 \pm 5.6$ \\
\hline$a$ & 14.6 & 5.4 & 9.2 & $1: 1.70$ & a) \\
\hline$b$ & & 9.1 & 5.5 & $1: 0.60$ & ${ }^{\text {a) }}$ \\
\hline$c$ & 15.9 & 5.9 & 10.0 & $1: 1.70$ & ${ }^{\text {a) }}$ \\
\hline$d$ & & 9.9 & 6.0 & $1: 0.61$ & $12.0 \pm 0.6$ \\
\hline$e$ & 17.4 & 6.4 & 11.0 & $1: 1.72$ & a) \\
\hline$f$ & & 11.1 & 11.1 & $1: 0.60$ & $20.4 \pm 2.2$ \\
\hline$g$ & 18.6 & 6.8 & 11.6 & $1: 1.71$ & $261.7 \pm 6.3$ b) \\
\hline$h$ & & 11.6 & 7.0 & $1: 0.60$ & $\left.277.2 \pm 4.5^{b}\right)$ \\
\hline$i$ & 21.3 & 13.3 & 8.0 & $1: 0.60$ & $286.0 \pm 6.0$ \\
\hline$j$ & 23.8 & 14.8 & 9.0 & $1: 0.61$ & $275.3 \pm 2.3^{\text {b) }}$ \\
\hline$a$ & 11.7 & 5.7 & 6.0 & $1: 1.05$ & ${ }^{\text {a) }}$ \\
\hline$b$ & 12.6 & 6.1 & 6.5 & $1: 1.07$ & $23.8 \pm 0.2$ \\
\hline$c$ & 13.6 & 6.6 & 7.0 & $1: 1.06$ & $68.0 \pm 7.8$ \\
\hline$d$ & 14.6 & 7.1 & 7.5 & $1: 1.06$ & $216.6 \pm 9.3$ \\
\hline$e$ & 15.6 & 7.6 & 8.0 & $1: 1.05$ & $213.6 \pm 1.1$ \\
\hline$f$ & 16.5 & 8.0 & 8.5 & $1: 1.06$ & $254.8 \pm 3.1$ \\
\hline$g$ & 17.5 & 8.5 & 9.0 & $1: 1.06$ & $230.9 \pm 4.5$ \\
\hline & & & & & \\
\hline
\end{tabular}

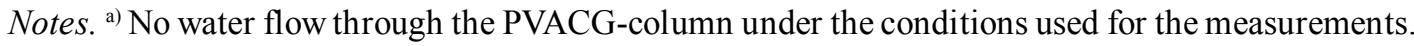

b) A cryogel sample with very high heterogeneity along the column height and containing cavities close by the syringe wall.

1) The first group (samples $1 a-1 e$ ) is the case when the total concentration of PVA and GuAr was varied, but their ratio was maintained constant $(1: 1, \mathrm{w} / \mathrm{w})$.

2) For the second group (samples $2 a-2 h$ ), the GuAr / PVA ratio was either $1: \sim 1.7(\mathrm{w} / \mathrm{w})$, or 1: 0.6 (w/w) for each total polymer concentration value. In the cases of [PVA+GuAr] $=21.3$ and 23.8 wt. $\%$ (samples $2 i$ and $2 j$ ) the ratio $1: \sim 1.7$ was not considered because of the experimental difficulties in preparing too viscous stock solutions with high PVA concentration.

3) The third group concerns the samples $3 a-$ $3 g$ prepared so that the GuAr/PVA ratio in the initial feeds was about $1: 1.05-1.07(\mathrm{w} / \mathrm{w})$, which was close to the points being onto the rectilinear diameter of the phase diagram (Fig. 3).

It turned out that the well-manifested wide pore morphology along the height of respective PVACG columns was formed when the initial total concentration of both polymers was higher than $\sim 14$ wt. $\%$ provided that the GuAr/PVA ratio was $\sim 1: 1$ (Table 3 , nos. $1 c-1 e$ and $3 d-3 g$ ). At initial PVA $+\mathrm{GuAr}$ content in the feeds lower than $\sim 13.6$ wt. $\%$, either cryogels without interconnected gross pores (Table 3, nos. $1 a$ and $3 a$ ), or samples with reduced "flow permeability" (nos. $3 b$ and $3 c$ ) were formed. Besides, similar results were observed when the GuAr/PVA weight ratios in the initial feeds were far from $1: 1$, namely, either $1: \sim 1.7$, or $1: \sim 0.6$, (samples $2 a-2 f$ in Table 3). However, when at the same $\mathrm{GuAr} / \mathrm{PVA}$ ratios the initial PVA+GuAr sum concentration was higher than 17-18 wt. \%, we obtained wide-porous PVACGs (nos. $2 g$ - $2 j$ ) with a very non-uniform macroporosity along the height of cryogel column, and the samples even included some cavities close by the inner surface of the syringe wall. So, from these data follows that PVA cryogels possessing a more or less 
macroscopically regular system of interconnected wide pores within the whole volume of the samples can be prepared over a rather narrow concentration range for both used polymeric components, PVA and GuAr.

Micrographs in Fig. 4 show at two magnifications the morphology of a 2-mm-thick disc (see section 2.2.7) of such wide pore PVACG sample ( $3 c$ in Table 3). The dark areas in these pictures are the proper PVA cryogel phase stained with Congo red, the clear areas are the pores of various shape and size. The gross through-hole pores with the cross-section of around 100-1000 micrometers are clearly seen at low magnification (Fig. 4, a). At a 5 times higher resolution (Fig. 4, $b$ ) one can also distinguish the porosity of the gel matter proper, which is the continuous phase in such spongy heterogeneous material. The roundish pores here are of 110 micrometers in cross-section. Thus, at least two distinct types of macropores differing significantly in their size are seen (with a light microscope) to exist in such cryogel discs prepared by combining the liquid-liquid phase separation and cryotropic gelation processes.

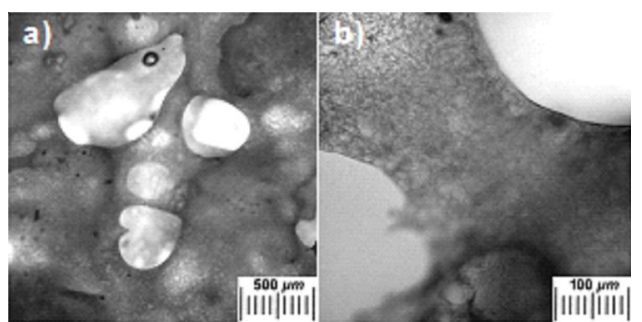

Fig. 4. Survey micrographs of the $2 \mathrm{~mm}$-thick disc of a wide pore PVACG sample prepared from the feed system with $\mathrm{pH} 5.3$ (\# 3c, Table 3)

\subsection{Properties of PVACGs Formed from the Feeds with Alkaline pH Values}

Since GuAr macromolecules contain numerous pendant carboxylic groups, the water-binding ability of this biopolymer strongly depends on whether or not these groups are in the ionized or non-dissociated forms. In turn, the solvation extent of GuAr should influence the liquid-liquid phase equilibrium in the waterPVA-GuAr ternary systems including those to be used for the preparation of the wide pore PVACGs. Therefore, we experimented with the systems of various (11.7-16.5 wt. \%) total polymer concentrations, at about the same
GuAr/PVA weight ratio $(1: \sim 1.06)$ and at different $\mathrm{pH}$ values (from 5.3 to 11 ) of the initial feeds, and compared the properties of resulting cryogels. Table 4 summarizes the hydrodynamic properties of the PVACG-columns as well as the Young's moduli (see section 2.2.6 and Fig. 2) of the samples. In addition, the non-spongy cryogels without GuAr component (nos. $7 a-7 d$, Table 4) were also prepared from the $8.5 \%$ solutions of gel-forming polymer with different $\mathrm{pH}$ values in order to trace the influence of $\mathrm{pH}$ variation per se on the rigidity of the respective PVA cryogels.

Note first of all that more or less marked effects of the feed's $\mathrm{pH}$ on the water flow rates through the wide pore cryogel columns were observed only for the systems with relatively low (11.7-13.6 wt. \%) PVA+GuAr total concentration (example groups 1-3, Table 4), when the passage to the ionized form of $\mathrm{GuAr}$ resulted in a stepwise increase in the FR values for spongy PVACGs (cf. examples $a$ and $b-c$ for the groups 1-3 in Table 4). At the same time, in the systems with higher total polymer concentration (groups 4-6) such an influence was negligible: at $[\mathrm{PVA}+\mathrm{GuAr}]=$ 14.6-16.6 wt. \% the FR values for all the column samples exceeded $210 \mathrm{~mL} / \mathrm{h}$. This clearly indicates the wide-porous morphology of respective cryogels.

Two similar "regions" were observed in the feed's $\mathrm{pH}$ influence on the physical and mechanical properties of the cryogels under study. Over the range of $[\mathrm{PVA}+\mathrm{GuAr}]=11.7$ 13.6 wt. \%, only a weak (without any evident trend) differences were registered in the Young's modulus for the gel samples formed from the equiconcentrated feeds of various $\mathrm{pH}$, whereas at $[\mathrm{PVA}+\mathrm{GuAr}]=14.6-16.6 \mathrm{wt}$. \% the cryogels prepared from the "alkaline" feeds were stronger than those formed from PVA+GuAr solutions without any $\mathrm{pH}$ adjustment, i.e. at $\mathrm{pH}$ 5.3. The latter effect was best visible for the samples with the highest PVA concentration (group 6, Table 4), and qualitatively the tendency was the same as for the non-spongy PVA cryogels prepared without GuAr additives (group 7, Table 4): the more alkaline was the initial feed, the stronger was the resulting PVACG. Note that a similar reinforcing effect of alkaline $\mathrm{pH}$ values on the "conventional" PVA cryogels was also reported elsewhere [55]. 
Influence of the pH of the initial water-PVA-GuAr feeds on the physical and chemical properties of resulting wide pore PVACGs

\begin{tabular}{|c|c|c|c|c|c|c|}
\hline \multirow[b]{2}{*}{$\begin{array}{l}\text { Example } \\
\text { number }\end{array}$} & \multicolumn{4}{|c|}{ Composition of the initial feed } & \multirow[b]{2}{*}{$\begin{array}{c}\text { FR } \\
(\mathrm{mL} / \mathrm{h})\end{array}$} & \multirow[b]{2}{*}{$\begin{array}{c}E \\
(\mathrm{kPa})\end{array}$} \\
\hline & $\begin{array}{l}\text { Total concentration } \\
\text { of the polymeric } \\
\text { components (wt. \%) }\end{array}$ & $\begin{array}{l}\text { GuAr concent- } \\
\text { ration in the } \\
\text { feed (wt. } \% \text { ) }\end{array}$ & $\begin{array}{l}\text { PVA concent- } \\
\text { Ration in the } \\
\text { feed (wt. \%) }\end{array}$ & $\mathrm{pH}$ & & \\
\hline $1 a$ & 11.7 & 5.7 & 6.0 & $5.3^{\text {a) }}$ & b) & $2.14 \pm 0.09$ \\
\hline$b$ & & & & 9.0 & $219.6 \pm 4.5$ & $3.08 \pm 0.32$ \\
\hline$c$ & & & & 10.0 & $240.0 \pm 2.5$ & $2.95 \pm 0.30$ \\
\hline$d$ & & & & 11.0 & $228.4 \pm 8.4$ & $2.61 \pm 0.42$ \\
\hline $2 a$ & 12.6 & 6.1 & 6.5 & $5.3^{\text {a) }}$ & $23.8 \pm 0.2$ & $3.15 \pm 0.78$ \\
\hline$b$ & & & & 9.0 & $215.4 \pm 2.0$ & $3.94 \pm 0.40$ \\
\hline$c$ & & & & 10.0 & $219.9 \pm 2.9$ & $3.35 \pm 0.60$ \\
\hline$d$ & & & & 11.0 & $240.7 \pm 1.9$ & $3.45 \pm 0.35$ \\
\hline $3 a$ & 13.6 & 6.6 & 7.0 & $5.3^{\text {a) }}$ & $68.0 \pm 7.8$ & $3.46 \pm 0.48$ \\
\hline $\bar{b}$ & & & & 9.0 & $222.5 \pm 7.6$ & $3.84 \pm 1.04$ \\
\hline$c$ & & & & 10.0 & $242.0 \pm 8.0$ & $3.32 \pm 0.71$ \\
\hline$d$ & & & & 11.0 & $239.9 \pm 6.1$ & $3.64 \pm 0.68$ \\
\hline $4 a$ & 14.6 & 7.1 & 7.5 & $5.3^{\text {a) }}$ & $216.6 \pm 9.3$ & $4.19 \pm 0.51$ \\
\hline$b$ & & & & 9.0 & $249.3 \pm 1.1$ & $5.03 \pm 1.45$ \\
\hline$c$ & & & & 10.0 & $243.5 \pm 1.3$ & $4.53 \pm 2.17$ \\
\hline$d$ & & & & 11.0 & $237.5 \pm 1.5$ & $4.92 \pm 1.26$ \\
\hline $5 a$ & 15.6 & 7.6 & 8.0 & $5.3^{a)}$ & $213.6 \pm 1.1$ & $4.57 \pm 1.15$ \\
\hline$b$ & & & & 9.0 & $229.0 \pm 9.0$ & $6.61 \pm 2.67$ \\
\hline$c$ & & & & 10.0 & $228.7 \pm 2.5$ & $6.73 \pm 3.17$ \\
\hline$d$ & & & & 11.0 & $222.6 \pm 2.8$ & $5.31 \pm 2.63$ \\
\hline $6 \quad a$ & 16.5 & 8.0 & 8.5 & $5.3^{\text {a) }}$ & $254.8 \pm 3.1$ & $6.47 \pm 0.91$ \\
\hline$b$ & & & & 9.0 & $236.3 \pm 5.5$ & $7.80 \pm 1.80$ \\
\hline$c$ & & & & 10.0 & $239.7 \pm 0.4$ & $8.53 \pm 0.89$ \\
\hline$d$ & & & & 11.0 & $232.9 \pm 2.8$ & $10.0 \pm 1.1$ \\
\hline $7 \quad a$ & 8.5 & - & 8.5 & $5.3^{\text {a) }}$ & - & $4.59 \pm 0.47$ \\
\hline$b$ & & & & 9.0 & - & $6.68 \pm 0.66$ \\
\hline$c$ & & & & 10.0 & - & $9.33 \pm 0.49$ \\
\hline$d$ & & & & 11.0 & - & $11.3 \pm 1.3$ \\
\hline
\end{tabular}

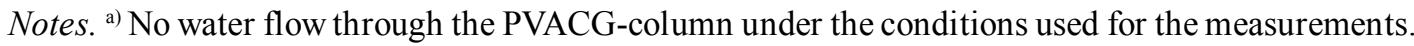
${ }^{\text {b) }} \mathrm{pH}$ value of the initial feed without any additional $\mathrm{pH}$ adjusting.

So, we conclude that the effect of feed's alkaline $\mathrm{pH}$ on the strength of PVA-rich gel phase in these heterophase cryogels consists mainly in favoring the cryotropic gel-formation of PVA proper, whereas its impact on the wide-porous architecture of such spongy cryogels is due to the ionized state of GuAr macromolecules influencing the formation of separated GuAr-rich phase. It was important therefore to elucidate how the shift in the feed's $\mathrm{pH}$ can influence the phase equilibrium of the liquid ternary system water-PVA-GuAr. Therefore, the phase diagram of this system at $\mathrm{pH} 10$ has been determined (Fig. 5) and compared with that of the system without pH adjustment (Fig. 3, see the discussion above).

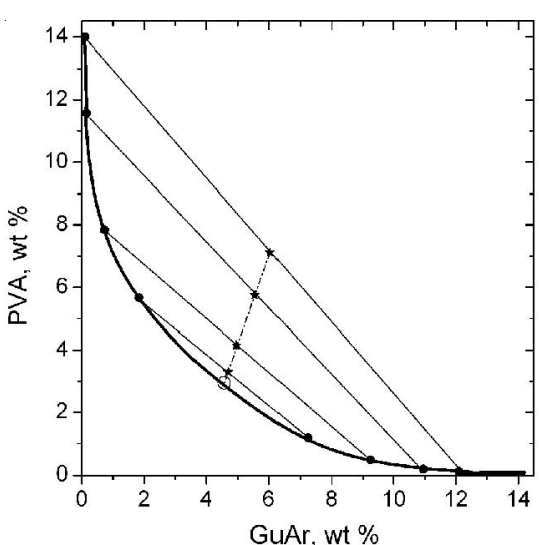

Fig. 5. Isothermal $\left(20^{\circ} \mathrm{C}\right)$ phase diagram of water-PVA-GuAr system at $\mathrm{pH} 10.0$ :

thick full line - binodal; thin full line - tie line; dotted line - rectilinear diameter; $\bullet$ - phase composition; o - critical point; * - threshold point 
The main difference in thermodynamic compatibility of PVA with GuAr at $\mathrm{pH} 10$ from that at $\mathrm{pH} 5.3$ consisted in the wider concentration range answering to the two-phase state (Fig. 5 and Table 2). The total concentration of the polymers in the critical point $\left(C_{t}^{\text {cr }}\right)$ at $\mathrm{pH} 10$ was 7.5 wt. \% instead of $9.6 \mathrm{wt} . \%$ at $\mathrm{pH}$ 5.3. The total concentration in the threshold point $\left(C_{t}^{*}\right)$ was also slightly less (7.25 wt. \%) than that found at $\mathrm{pH} 5.3$ (8.85 wt. \%). The limit of PVA solubility (0.1 wt. \%) in the concentrated solutions of GuAr and the limit of GuAr solubility ( $0.1 \mathrm{wt}$. \%) in the concentrated solutions of PVA were very small. It is known that the zeta potential of many polyelectrolytes can be significantly diminished in the presence of PVA, especially in alkaline range [51]. We can therefore assume that slightly smaller compatibility of PVA with $\mathrm{GuAr}$ in the alkaline range of $\mathrm{pH}$ is the result of the decrease in the zeta potential of GuAr at $\mathrm{pH}$ 10. Comparing the phase diagrams of the water-PVA-GuAr system obtained at different $\mathrm{pH}$ values we conclude that the conditions favourable for obtaining the wide pore PVACGs are as follows: the total concentration of the polymers higher than 7.5-9.6 wt. \% (depending on $\mathrm{pH}$ ), more or less similar concentrations of PVA and GuAr in the ternary feed system, and, preferably, alkaline $\mathrm{pH}$ value.

The characteristic morphology of the cryogel samples prepared from the feed with alkaline $\mathrm{pH}$ (pH 10 in this particular case) is exemplified by the micrographs in Fig. 6 given in the same fashion as those in Fig. 4 for the PVACG disc prepared from the feed with $\mathrm{pH} 5.3$ and the same polymer content and GuAr/PVA ratio. In both cases one can see very similar channel-like through-hole wide pores ( $c f$. Fig. $4, a$, and $6, a$ ) and also porous morphology of the gel phase proper (Fig. $4, b$, and $6, b)$. The pore shape and their dimensions in this phase (the gel walls of wide pores) turned out to be of the same order $(1-10 \mu \mathrm{m})$ for both kinds of PVACGs, as well as for the cryogels prepared from the equi-concentrated feeds with pH 9 and 11 (their micrographs are not given in Fig. 6 because of close similarity of the respective images). Thus the feed's $\mathrm{pH}$ in the range of 5.311 has almost no effect on the porous morphology of the walls of gross pores, at least for the wide pore PVACG samples obtained from the feeds with $[\mathrm{PVA}+\mathrm{GuAr}] \geq \sim 14$ wt. \% (groups 4-6 in Table 3).

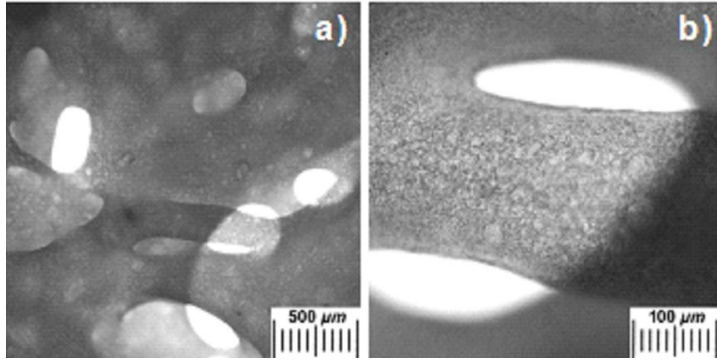

Fig. 6. Survey micrographs of the $2 \mathrm{~mm}$-thick disc of a wide pore PVACG sample prepared

from the feed system with $\mathrm{pH} 10$ (\# 4c, Table 4)

3.4. Interaction of PVA and GuAr within the PVA-Rich Gel Phase of Wide Pore PVACGs

The data in Tables I and II show that GuAr concentrations in the PVA-rich liquid phase $\left(\mathrm{C}_{\mathrm{GuAr}}{ }^{\lim }\right)$ are low at both $\mathrm{pH}$ values tested. However, it was unclear whether or not this GuAr is incorporated into the supramolecular network of freeze-thaw-forming gel phase of wide pore heterophase PVACG at different feed's $\mathrm{pH}$ values and, if it is, to what extent such "incorporated" GuAr could be washed out from the cryogel matrix during the rinsing stage (section 2.2.3).

To answer this question we have prepared wide pore PVACG samples from the feeds with $[\mathrm{PVA}+\mathrm{GuAr}]=15.6 \mathrm{wt} . \%$ and $\mathrm{GuAr} / \mathrm{PVA}$ $=1: 1.05(\mathrm{w} / \mathrm{w})$ at $\mathrm{pH} 5.3$ and 10.0 (Table 4, nos. $7 a$ and $7 c$, respectively), rinsed the columns either with pure water or with $0.1 \mathrm{~N} \mathrm{NaOH}$ solution followed by pure water, then melted these cryogels, prepared the thin films from the polymer solutions thus obtained (see 'Experimental'), and recorded their FTIR spectra (Fig. 7 and 8).

The spectra ' $a$ ' and ' $b$ ' in Fig. 7 correspond to the individual polymers we used (these spectra are typical for PVA [16] and GuAr [14]), while the spectra ' $c$ ' and ' $d$ ' have been obtained for the films prepared from the PVACGs formed at $\mathrm{pH} 5.3$ and 10.0 and then rinsed with water only. The differences in the spectra of the two initial polymers most significant for the present study are in the range of $1600-1620 \mathrm{~cm}^{-1}$, where GuAr has a band at $1608 \mathrm{~cm}^{-1}$ characteristic for the COOasymmetric stretching vibrations $\left(v^{\text {as }}\right)$ [14] and indicated in the spectrum ' $b$ ' by an asterisk. Since this peak is absent in the FTIR spectrum ' $a$ ' of neat PVA, it was possible using such "band of interest", to evaluate, qualitatively at least, the presence of GuAr admixtures in the 
respective wide pore cryogels prior to and after the rinsing stage. Indeed, the band at around $1608 \mathrm{~cm}^{-1}$ is observed for the films derived from the above-indicated PVACGs (spectra ' $c$ ' and ' $d$ ') thus proving the entrapment of a certain amount of GuAr in the gel phase of spongy cryogels prepared from the feeds both with pH 5.3 and 10.

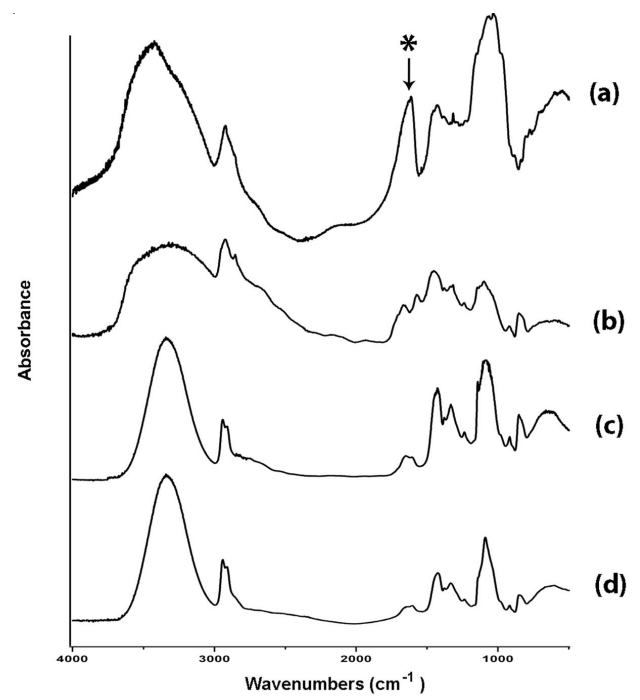

Fig. 7. FTIR spectra of the thin films prepared via the procedure of section 2.2.7 from the following polymers and cryogels:

$a$ - GuAr; $b$ - PVA; $c$ - PVACG (\# $4 a$, Table 4); $d$ - PVACG (\# 4c, Table 4)

Besides, the presence of the "band of interest" in the vicinity of $1608 \mathrm{~cm}^{-1}$ in the spectra ' $c$ ' and ' $d$ ' (Fig. 7) testifies that GuAr interacts rather strongly with PVA within the gel phase of the studied PVACGs, since GuAr with its high solubility in water was not washed-off from these cryogels even upon passing of 100 volumes of pure water through each syringe filled with the wide pore gel matrices. It should be noted in this context that a similar strong interaction of $\mathrm{COOH}$-bearing macromolecules (polyacrylic acid, mainly) with PVA in the composition of some complex PVACGs is well known, and this phenomenon is associated with the formation of multiple hydrogen bonds between the OH-groups of PVA and carboxyl groups of the second polymer $[13 ; 68 ; 71]$. So, in the case we have studied, the nature of the GuAr-PVA intermolecular contacts in the PVA-rich gel phase is obviously the same; moreover a similar interaction has been described for this pair of polymers [24].

We have further used FTIR spectroscopy to study the possibility of extracting such $\mathrm{H}$-bound $\mathrm{GuAr}$ "admixtures" from the wide pore PVA cryogels prepared on the basis of water-PVA-GuAr systems. When such PVACGs were prepared without the adjustment of the feed's $\mathrm{pH}$, i.e. at $\mathrm{pH}$ 5.3, subsequent alkaline rinsing was able to wash away $\mathrm{GuAr}$ from the respective PVACG ( $c f$. spectra ' $a$ ' and ' $b$ ' in Fig. 8). However, it was not so in the case of mixed PVA/GuAr-cryogels fabricated from the feeds with alkaline $\mathrm{pH}$, e.g. $\mathrm{pH}$ 10.0: neither rinsing with pure water, nor alkaline rinsing under the conditions used (see section 2.2.3), was able to wash away completely this poly(peptidoglucane) from the gel phase of such wide pore PVACGs: the asteriskindicated GuAr-specific band was present in the FTIR spectrum of the film fabricated from this cryogel ( $c f$. spectra ' $c$ ' and ' $d$ ' in Fig. 8). This proves a very strong association of GuAr with PVA during freeze-thaw gelation of the alkaline mixed polymeric system, so that the former macromolecules are obviously incorporated into the 3D network of the latter polymer.

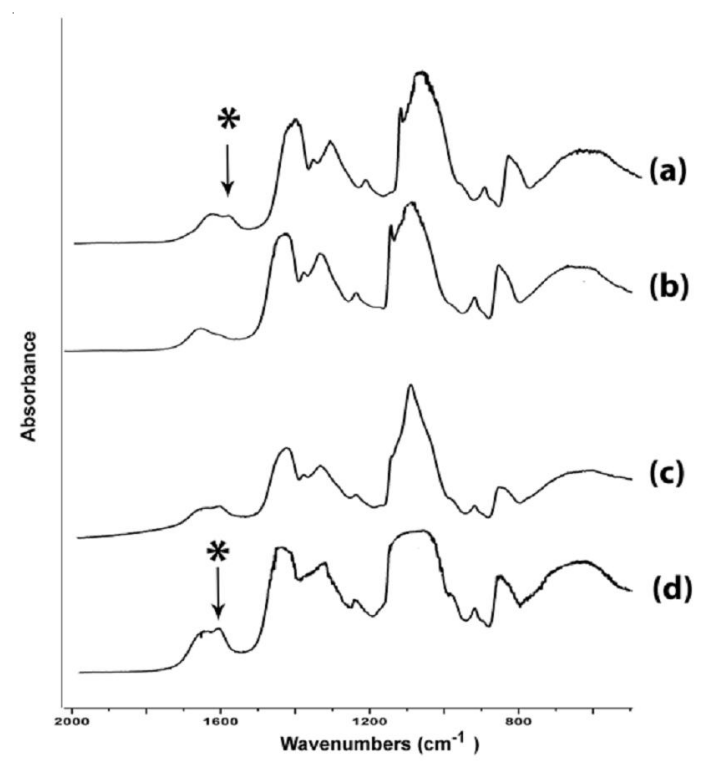

Fig. 8. The part of FT-IR spectra of the thin films prepared via the procedure of section 2.2.7 from the following cryogels:

$a$ - PVACG (\# 4a, Table 4) rinsed with pure water; $b$ - PVACG (\# 4a, Table 4) rinsed with $0.1 \mathrm{~N} \mathrm{NaOH}$ followed by pure water;

$c$ - PVACG (\# 4c, Table 4) rinsed with pure water; $d$ - PVACG (\# 4c, Table 4) rinsed with $0.1 \mathrm{~N} \mathrm{NaOH}$ followed by pure water 
This necessarily leads to the question: what is the chemical nature of so strong an association between PVA and GuAr in the gel phase of such spongy PVACGs prepared from the "alkaline" feed?

Indeed, it is well established (e. g., see refs. $[24 ; 30 ; 68 ; 71])$ that efficient H-bonding of PVA with weak poly(carbonic acids) such as, e. g., polyacrylic or polymethacrylic ones, occurs when their $\mathrm{COOH}$-groups are in the non-ionized state. When the $\mathrm{pH}$ is shifted to the alkaline zone, the carboxyls are inonized, which results in splitting of interchain hydrogen bonds and break-up of interpolymer associates [30]. Therefore, the efficiency of the alkaline rinsing for GuAr removal from the spongy PVACGs prepared from the feed systems with $\mathrm{pH} 5.3$ agrees well with this concept: at mildly acidic $\mathrm{pH}$ the PVA-GuAr associates are stabilized, whereas at the alkaline $\mathrm{pH}$ (rinsing with $0.1 \mathrm{~N} \mathrm{NaOH}$ ) these $\mathrm{H}$-bound associates are decomposed. Hence, in the case of mixed PVAGuAr cryogel formation under alkaline conditions (all the samples of $b$ - $d$ type in Table 4) a weaker interaction between these two polymers and easier removal of GuAr from the PVA cryogel matrix can be expected. In fact, as was mentioned above, the opposite effect was observed - we were unable to wash away GuAr completely from the respective (prepared at $\mathrm{pH} \mathrm{10)} \mathrm{spongy} \mathrm{PVACGs} \mathrm{under} \mathrm{the}$ conditions capable of rinsing the cryogel samples formed at $\mathrm{pH} 5.3$.

At present, the exact nature of the forces responsible for such an effect is yet unclear; we can only hypothesize on possible mechanisms. For instance, since GuAr includes the polypeptide core along with acidic polysaccharide moieties, the pendant functional groups of certain amino acid residues can interact with deprotonated (under alkaline conditions) hydroxylic groups of PVA chains. The "suspects" among such amino acids are the basic ones - lysine, arginine, and histidine, which are present in GuAr macromolecules in the amount of 70-90 pieces per 1000 residues [77]. The side functional basic groups of such amino acids (amino, guanidine, and imidazole, respectively) in alkaline media exist partially (depending on the $\mathrm{pH}$ ) in the ammonium forms that can potentially bind with negatively-charged deprotonated hydroxyls of PVA. Similar binding was earlier observed in the case of composite PVA cryogels filled with particles of anion-exchange resin DEAE-Sephadex, when exactly the $\left(\mathrm{OH}^{-}\right)$-form of the resin - the ammonium form of alkylated amino groups - did cause a significant reinforcement of the composite, whereas the $\mathrm{H}^{+}$or $\mathrm{Cl}^{-}$forms did not [62]. Note also that the polyelectrolyte upswelling of GuAr in alkaline media hinders sterically the access of GuAr polypeptide regions to PVA chains thus facilitating additional interactions of these two polymers, and at the same time resulting in liberation of the low molecular counter-ions, which will also increase the entropy of the system.

Yet another fact testifying a rather strong association of GuAr macromolecules with PVA within the gel phase of spongy cryogels studied is the dependence of PVACGs' fusion temperatures on the conditions used for rinsing these heterophase gels (Table 5).

The trends observed were as follows:

(i) Over the range of $[\mathrm{PVA}+\mathrm{GuAr}]=12.6-$ 17.5 wt. $\%$ and at $\mathrm{GuAr} / \mathrm{PVA}=1:(1.05-1.07)(\mathrm{w} /$ w) the values of $T_{f}$ for the water-rinsed PVACGs prepared from the feeds with $\mathrm{pH} 5.3$ (samples ' $a$ '; Table 5) were by $1.9-4.4{ }^{\circ} \mathrm{C}$ lower than the fusion temperatures of respective equi-concentrated cryogels prepared from the feeds with $\mathrm{pH} 10$ (samples ' $b$ '; Table 5). This indicates a higher amount of thermally-fusible interchain links in the junction knots of the 3D network of the latter PVACGs as compared to the former ones. The main such links in PVA cryogels are the $\mathrm{H}$ bonds [27] responsible for the stabilization of intermolecular contacts within the microcrystallites that, in turn, play the role of the above-mentioned knots $[19 ; 60 ; 61]$. So, the somewhat higher heat endurance of the samples ' $b$ ' can be attributed to the above-discussed supposed interactions between the PVA chains and the segments of the polypeptide core of GuAr macromolecules.

(ii) At the same time, when the cryogel samples of the ' $a$ ' type were initially rinsed with alkaline solution and then with water, the differences between the $T_{f}$ for samples ' $a$ ' and ' $b$ ' became either insignificant in the cases of [PVA+GuAr] = 12.6-14.6 wt. $\%$ (nos. 1-3, Table 5) or even reversed in the cases of $[\mathrm{PVA}+\mathrm{GuAr}]=15.6$ 17.5 wt. $\%$ (nos. 4-6) when the ' $a$ ' type samples were more thermostable than the ' $b$ ' type ones. We can conclude from these data that alkaline rinsing not only removes the GuAr admixtures from the gel phase of such spongy PVACGs, but also assists the formation of a greater amount of PVA- 
Influence of rinsing conditions on the fusion temperature of wide pore PVACGs

\begin{tabular}{|c|c|c|c|c|c|c|}
\hline \multirow[b]{3}{*}{$\begin{array}{l}\text { Example } \\
\text { number }\end{array}$} & \multicolumn{4}{|c|}{ Composition of the initial feed } & \multirow{2}{*}{\multicolumn{2}{|c|}{$\begin{array}{c}\text { Fusion temperature }\left(T_{f}\right) \\
\text { of PVACGs }\left({ }^{\circ} \mathrm{C}\right)\end{array}$}} \\
\hline & \multirow[b]{2}{*}{$\begin{array}{c}\text { Total } \\
\text { concentration } \\
\text { of the polymeric } \\
\text { components } \\
\text { (wt. \%) }\end{array}$} & \multirow{2}{*}{$\begin{array}{l}\text { GuAr } \\
\text { concentra- } \\
\text { tion } \\
\text { in the feed } \\
\text { (wt. } \% \text { ) }\end{array}$} & \multirow[b]{2}{*}{$\begin{array}{c}\text { PVA } \\
\text { concentra- } \\
\text { tion } \\
\text { in the feed } \\
(\text { wt. } \%)\end{array}$} & \multirow[t]{2}{*}{$\mathrm{pH}$} & & \\
\hline & & & & & $\begin{array}{c}\text { Column } \\
\text { rinsed with } \\
\text { pure water }^{\text {a) }}\end{array}$ & $\begin{array}{l}\text { Column rinsed } \\
\text { with alkaline } \\
\text { solution followed } \\
\text { by pure water }{ }^{\text {b) }}\end{array}$ \\
\hline $1 \quad a$ & 12.6 & 6.1 & 6.5 & 5.3 & $69.2 \pm 1.7$ & $73.3 \pm 1.3$ \\
\hline$b$ & & & & 10.0 & $71.1 \pm 0.7$ & $74.2 \pm 0.4$ \\
\hline $2 a$ & 13.6 & 6.6 & 7.0 & 5.3 & $70.6 \pm 1.0$ & $74.6 \pm 0.4$ \\
\hline$b$ & & & & 10.0 & $73.3 \pm 1.1$ & $74.6 \pm 0.6$ \\
\hline $3 a$ & 14.6 & 7.1 & 7.5 & 5.3 & $71.7 \pm 1.1$ & $75.8 \pm 0.6$ \\
\hline$b$ & & & & 10.0 & $73.7 \pm 1.1$ & $75.9 \pm 0.5$ \\
\hline $4 \quad a$ & 15.6 & 7.6 & 8.0 & 5.3 & $72.5 \pm 0.9$ & $77.2 \pm 0.4$ \\
\hline$b$ & & & & 10.0 & $75.5 \pm 0.3$ & $76.2 \pm 0.8$ \\
\hline $5 \quad a$ & 16.6 & 8.1 & 8.5 & 5.3 & $73.3 \pm 0.5$ & $77.9 \pm 0.9$ \\
\hline$b$ & & & & 10.0 & $76.4 \pm 0.6$ & $76.9 \pm 0.7$ \\
\hline $6 \quad a$ & 17.5 & 8.5 & 9.0 & 5.3 & $73.5 \pm 1.0$ & $79.2 \pm 1.2$ \\
\hline$b$ & & & & 10.0 & $77.9 \pm 0.9$ & $77.9 \pm 0.7$ \\
\hline
\end{tabular}

Notes. ${ }^{\text {a) }}$ Each 3-mL PVACG cylinder inside a syringe was rinsed with $300 \mathrm{~mL}$ of deionized water in a flow-through mode (see section 2.2.3).

b) Each 3-mL PVACG cylinder inside a syringe was rinsed with $30 \mathrm{~mL}$ of $0.1 \mathrm{~N} \mathrm{NaOH}$ solution followed by $300 \mathrm{~mL}$ of deionized water.

PVA intermolecular H-bonds in the junction knots of the supramolecular network of these heterophase gel matrices. One possible route of such assistance can be the replacement of PVAGuAr H-bonding by the novel 'additional' PVAPVA contacts after the GuAr alkaline extraction. Obviously the same mechanism also works (at least in part) in the ' $b$ '-type samples, since their fusion temperatures after alkaline rinsing have somewhat increased as well. However, this trend becomes less pronounced as the total initial concentration of PVA and GuAr increases (their ratio remaining constant). This obviously means that at higher PVA content in the initial mixed system (pH 10) to be structured cryogenically the contribution of the above-discussed GuAr-PVA interactions to the integral thermal properties of the resulting PVACGs is overpowered by the intense processes of cryotropic gelation of the PVA per se (the higher the feed PVA concentration, the stronger and the higher-melting is the respective PVACG).

3.5. Hierarchical Porous Morphology of Cryogels Formed on the Basis of WaterPVA-GuAr Systems

The porous morphology of PVACGs formed by the combination of liquid-liquid phase separation and cryotropic gel-formation processes in the water-PVA-GuAr ternary systems is governed by the united, often simultaneous, action of diverse factors. It is very difficult therefore to reveal the particular effect of each of these factors individually. That is why in this study we have traced only the main morphological features of the resulting gel matrices. Some of these features were discussed above in the context of survey microscopy data (Fig. 4 and 6) obtained for the wide pore PVACGs molded as $2 \mathrm{~mm}$-thick discs. Additional information on the microstructure of similar gel systems has been acquired via the investigation of their thin sections with light microscopy - the technique successfully employed earlier for the analysis of various (conventional, complex and composite) PVAcryogels [33; 34; 62].

The micrographs in Fig. 9 show the typical images of such thin sections of two PVACG samples prepared from equi-concentrated feeds with different pH: 5.3 (Fig. 9, $a$, and 9, $b$ ) and 10.0 (Fig. 9, $c$ and $d$ ). Here, images ' $a$ ' and ' $c$ ' (given at relatively low resolution) show the general character of porous morphology of respective cryogels, whereas images ' $b$ ' and ' $d$ ' with 4 times higher magnification provide an insight into the structure of the proper gel phase of these spongy gel materials 


\section{ТЕХНИКО-ТЕХНОЛОГИЧЕСКИЕ ИННОВАЦИИ}

stained with Congo red (section 2.2.8), i.e. illustrate the structure of space between the gross pores.

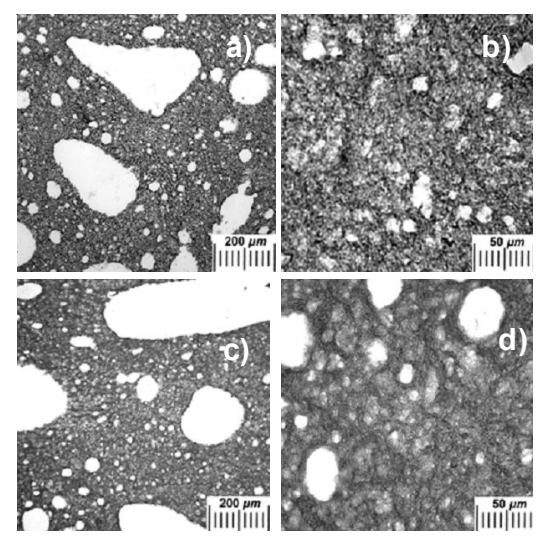

Fig. 9. Optical microscopy images of the stained with Congo red thin sections of wide pore PVACGs prepared from the feeds with $\mathrm{pH} 5.3$

(pictures ' $a$ ' and ' $b$ ') and $\mathrm{pH} 10$ (pictures ' $c$ ' and ' $d$ ') which corresponded

to the examples nos. $4 a$ and $4 c$ in Table 4

First of all, one can distinguish at least three kinds of pores within these gel matrices:

(i) very gross prolate pores with crosssection up to $100-200 \mu \mathrm{m}$ (those are also well seen in Fig. 4 and 6 as the channel-like pores);

(ii) roundish pores of about $10-70 \mu \mathrm{m}$ in diameter (some of them are slightly deformed see Fig. 8, $b$ );

(iii) and, at last, smaller pores, also rounded, of $\sim 1-5 \mu \mathrm{m}$ in diameter.

In other words, a definite hierarchy of porosity is observed in these PVACGs. Whereas the largest (i)-kind pores are, as can be well seen in Fig. 3, a, and $4, a$, interconnected (therefore liquids, water in this case, can easily leak through the blocks of such wide-porous cryogels - see Tables 3 and 4), the pores of the second (ii) and the third (iii) kinds are closed. It is clear that the former ones are the replicas of the continuous fraction of the GuArrich phase in the two-phase system formed as a result of liquid-liquid separation, when heterogeneous morphology of such a system is then fixed by cryotropic gelation of the PVA-rich phase. Since the cross-section of pores in conventional PVA cryogels generated by the ice polycrystals does not usually exceed $1-3 \mu \mathrm{m}[20 ; 32 ; 34 ; 40$ $42 ; 45 ; 46 ; 69 ; 70 ; 76 ; 80]$, it is evident that the 10 $70-\mu \mathrm{m}$-pores of the (ii)-sort are also replicas of the non-gelling GuAr-rich phase, but in this case dispersed as liquid droplets in the bulk of PVA-rich phase. And last, the smallest pores of (iii)-type (visible in light microscopy images, Fig. 9, $b$, and 9, d) are, most probably, left in the gel matter by the ice particles after their melting. Note that the pores of the latter type have a rounded shape, whereas those observed in the PVACGs prepared under the same conditions from the aqueous PVA solutions without foreign polymeric additives are usually anisodiametric (prolate) in their shape. At the same time, it was shown elsewhere that the round-shaped ice-derived pores in PVA cryogels are inherent in the gel matrices prepared with addition of surfactants [33] capable of influencing the shape of water crystals via the decrease in the surface tension at the solid-liquid interface. So, such "rounding" of the pores inside the gel phase of spongy PVACGs fabricated from water-PVAGuAr feeds can probably be due to certain surfactant properties of GuAr macromolecules present in a small amount in the initial PVA-rich phase (see values of $\mathrm{C}_{\mathrm{GuAr}}$ im in Table 2) prior to the system's freezing.

Further we discuss the differences in porous morphology of such wide pore PVA cryogels prepared from the feeds with distinct $\mathrm{pH}$ values. Thus, gross pores of the (i)-kind in PVACG formed at pH 5.3 (Fig. 9, a) were somewhat smaller than those in the samples fabricated at $\mathrm{pH} 10$ (Fig. 9, $c$ ). This agrees qualitatively with the lower water flow rates through the former cryogels (cf. FRs for the samples $4 a$ and $4 c$ in Table 4), since the narrower is the cross-section of the interconnected channels in similar wide pore cryogel matrices, the higher is, at equal hydrostatic pressure, the resistance to a flow and, hence, the lower the flow rate $[1 ; 33 ; 34]$. Yet another structural difference among the PVACG samples prepared from equiconcentrated feeds at pH 5.3 and 10 was the amount of the (iii)-kind pores inside the gel phase. The comparison of the images in Figs. 9, $b$, and 9, $c$, reveals greater number of such pores in the former cryogel, and their contour was much more definite than in the case of PVACG formed from alkaline feed, when the gel morphology turned out to be rather diffuse. However, no reliable correlation of these morphological features with, for instance, physical and mechanical properties of respective samples was detected either for the examples $4 a$ and $4 c$ (Table 4) and corresponding images $7 b$ and $7 d$, or for other PVACGs studied. The absence of such strict correlation evidently 
shows the sophisticated character of the influence of various factors on the properties and porous texture of these PVA cryogels whose formation concurs with liquid-liquid phase separation process.

\section{CONCLUSION}

Up to date various macroporous and supermacroporous (wide-porous) gel matrices have been considered and explored as prospective materials of biomedical application, in general, and for tissue engineering, in particular [25; 65]. Therefore, elaborating the approaches to the preparation of such matrices based on the nontoxic biocompatible natural and synthetic polymers is very topical (these approaches are known also to include the use of gel-forming liquid-liquid twophase polymeric systems) [17]. Such type of soft matter, as PVA cryogels, was also subject of much research in this context $[2 ; 7 ; 12 ; 33 ; 34]$. The wide pore PVACGs formed by the combination of liquid-liquid phase separation and cryotropic gelation phenomena can be prospective for biomedical applications. In the present research we explored the PVA cryogels prepared by freezing-thawing of water-PVA-GuAr feeds. To the best of our knowledge, such spongy PVACGs have not been studied before.

The set of conditions necessary for obtaining wide-porous (the cross-section of interconnected pores is around 100-200 $\mu \mathrm{m}$ ), permeable for a water flow, and, simultaneously, mechanically strong enough PVACGs has been established. These conditions are as follows. The total concentration of gelling component - PVA(MW of $86 \mathrm{kDa}$ ) and non-gelling polymer - GuAr (MW of $\sim 650 \mathrm{kDa}$ ) should exceed $\sim 14$ wt. \%, GuAr/PVA ratio should be near $1: 1(\mathrm{w} / \mathrm{w})$, and the feed's $\mathrm{pH}$ should be within the range of $\sim 5-11$. The phase diagrams created for the water-PVA-GuAr ternary liquid systems at $\mathrm{pH} 5.3$ and 10.0 have demonstrated that such "optimum" compositions are in the vicinity of the rectilinear diameters of respective diagrams, and that the limit of GuAr solubility in the PVArich phase is small. In such cases the GuAr fraction strongly binds with PVA, especially under alkaline conditions, within the forming gel phase of heterophase PVACG. The light microscopy studies revealed certain hierarchy of porous morphology inherent in these cryogels, namely, the presence of at least three kinds of pores was observed. First, there are interconnected channel-like gross pores with cross-section of 100-200 $\mu \mathrm{m}$ which are replicas of continuous GuAr-rich phase in the twophase polymeric systems appearing due to the liquid-liquid phase separation in the ternary waterPVA-GuAr system. The second type are isolated roundish large pores of about $10-70 \mu \mathrm{m}$ in diameter being the replicas of GuAr-rich phase dispersed as the liquid droplets in the PVA-rich phase. Third, there are smaller rounded pores of $\sim 1-5 \mu \mathrm{m}$ in diameter being the replicas of ice polycrystals. Such sophisticated "polyporous" morphology of the studied PVA cryogels is their unique feature distinguishing them from other PVA cryogels known so far.

\section{ACKNOWLEDGEMENTS}

The authors express their sincere gratitude to $\mathrm{PhD}$ Student O.E. Zaborina for the help in artwork preparation. This work was supported in part by the grants \# 12-03-91371-CT a from the Russian Foundation for Basic Research.

\section{REFERENCES}

1. Albertsson P.A. Partition of Cell Particles and Macromolecules. $2^{\text {nd }}$ ed. New York, WileyInterscience, $1971.346 \mathrm{p}$.

2. Alves M.H., Jensen B.E.B., Smith A.A.A., Zelikin A.N. Poly(vinyl alcohol) Physical Hydrogels: New Vista on a Long Serving Biomaterial. Macromol. Biosci., 2011, no. 11, pp. 1293-1313.

3. Antonov Yu.A., Van Puyvelde P., Moldenaers P. Flow-Induced Phase Behaviour and Structure Development in Aqueous Emulsion of Associative Biopolymers. Food Hydrocolloids, 2012, vol. 27, pp. 264-268.

4. Antonov Yu.A., Lozinskaya N. V., Grinberg V. Ya., Tolstoguzov V. B. Phase Equilibria in WaterProtein-Polysaccharide System. Colloid and Polymer Sci., 1979, no. 257, pp. 1159-1171.

5. Antonov Yu.A., Pletenko M.G., Tolstoguzov V.B. Termodinamicheskaya sovmestimost polisakharidov $\mathrm{v}$ vodnykh sredakh [Termodynamic Compatibility of Polysaccharides in Aqueous Media]. Vysokomolekulyarnye soedineniya, A, 1987, no. 29, pp. 2482-2486.

6. Arvidsson P., Plieva F.M., Savina I.N., Lozinsky V.I., Fexby S., Bulow L., Galaev I.Yu., 
Mattiasson B. Cryogels on the Basis of Natural and Synthetic Polymers: Preparation, Properties and Areas of Implementation. J. Chromatogr., 2002, vol. 977, pp. 27-38.

7. Bajpai A., Saini R. Designing of Macroporous Biocompatible Cryogels of PVA-Haemoglobin and Their Water Sorption Study. J. Mater. Sci., Mater. Med., 2009, vol. 20, pp. 2063-2074.

8. Bajpai A., Saini R. Preparation and Characterization of Spongy Cryogels of Poly(vinyl alcohol)Casein System: Water Sorption and Blood Compatibility Study. Polym. Int., 2005, vol. 54, pp. 796806. DOI: $10.1002 /$ pi.1773.

9. Bakhracheva Yu.S. Fracture Toughness Prediction by Means of Indentation Test. International Journal for Computational Civil and Structural Engineering, 2013, vol. 9, no. 3, pp. 21-24.

10. Baron A.A., Gevlich D.S., Bakhracheva Yu.S. Specific Plastic Strain Energy as a Measure of the Cracking Resistance of Structural Materials. Russian metallurgy (Metally), 2002, no. 6, pp. 587-592.

11. Cascone M.G., Barbani N., Maltini S., Lazzeri L. Gellan/poly(vinyl alcohol) Hydrogels: Characterization and Evaluation as Delivery Systems. Polym. Int., 2001, vol. 50, pp. 1241-1246.

12. Cascone M.G., Maltini S., Barbani N., Laus M. Effect of Chitosan and Dextran on the Properties of Poly(vinyl alcohol) Hydrogels. J. Mater. Sci., Mater. Med., 1999, vol. 10, pp. 431-435.

13. Choi J., Kung H.J., Macias C.E., Muratoglu O.K. Effects of Processing Parameters in Thermally Induced Phase Separation Technique on Porous Architecture of Scaffolds for Bone Tissue Engineering. J. Biomed. Mater. Res., Part B, Appl. Biomater., 2012, vol. 100, pp. 524-532.

14. Cui S.W., Phillips G.O., Blackwell B., Nikiforuk J. Quantication of the Degree of Blockiness in Pectins Using 1HNMR Spectroscopy and Chemometrics. Food Hydrocolloids, 2007, vol. 21, pp. 347-352.

15. Dai L.X., Ukai K., Shaheen S.M., Yamaura K. Gelation of a New Hydrogel System of AtacticPoly(vinyl alcohol)/NaCI/H2O. Polym. Int., 2002, vol. 51,pp. 715-720.

16. Edgren D., Zhu P.C., Struble E., Frame R., Zhang Y. A Novel Semi-Biobased Copolyester Containing Poly(trimethylene-co-hexamethylene terephthalate) and Poly(lactic acid) Segments. J. Macromol. Sci., Part A. Pure Appl. Chem., 2010, vol. 47, pp. 545-551.

17. Elbert D.L. Self-Assembled Composite Matrix in a Hierarchical 3D Scaffold for Bone Tissue Engineering. Acta Biomaterialia, 2011, vol. 7, pp. 31-56.

18. Gutiérrez M.C., Aranaz I., Ferrer M.L., Del Monto F. Macroporous Polymers: Production, Properties and Biological/Biomedical Applications. Boca Raton, CRC Press, 2010, pp. 83-115.
19. Hassan C.M., Ward J.H., Peppas N.A. Modeling of Crystal Dissolution of Poly(vinyl alcohol) Gels Produced by Freezing/Thawing Processes. Polymer, 2000, vol. 41, pp. 6729-6739.

20. Hassan Ch.M., Peppas N.A. Substituted and Ring-Substituted Water Soluble Self-Aciddoped Conducting Polyanilines and Their Blends With Poly(Vinyl Alcohol): Structure, Properties, and Applications. Adv. Polym. Sci., 2000, vol. 153, pp. 37-65.

21. Hatakeyama T., Yamaguchi A., Hatakeyama H. Effect of Thermal Hysteresis on Structural Change of Water Restrained in Poly(Vinyl Alcohol) Pseudo-Gel. Eur. Polym. J., 1987, vol. 23, pp. 361-365.

22. Hoskins P. R. Simulation and Validation of Arterial Ultrasound Imaging and Blood Flow. Ultrasound in Med. \& Biol., 2008, vol. 34, pp. 693-717.

23. Hsu C.C., Prausnitz J.M. Thermodynamics of Polymer Compatibility in Ternary Systems. Macromolecules, 1974, no. 7, pp. 320-324.

24. Ibrahim S.M., Ibrahim M.S., Farag S.A., Ragab A.A. The Mechanical Properties of Sago StarchFilled Linear Low Density. Polym. Plast. Technol. Eng., 2008, vol. 47, pp. 40-46.

25. Jagur-Grodzinski J. Polymers for Tissue Engineering, Medical Devices, and Regenerative Medicine. Concise General Review of Recent Studies. Polym. Adv. Technol., 2006, vol. 17, no. 6, pp.395-418.

26. Jiang H.J., Campbell G., Boughner D.R., Wan W.K., Quantz M. Design and Manufacture of Polyvinyl Alcohol (PVA) Cryogel Tri-Leaflet Heart Valve Prosthesis. Med. Eng. \& Phys., 2004, vol. 26, no. 4, pp. 269-277.

27. Kobayashi M., Ando I., Ishii T., Amiya S. Characterization of Jacalin, the Human IgA and IgD Binding Lectin From Jackfruit. J. Mol. Struct., 1998, vol. 440, pp. 155-164.

28. Koningsveld R., Staverman A.J. Phase Equilibria in Polymer Systems. J. Polym. Sci., 1968, vol. 6, pp. 305-323.

29. Lazzeri L. Carbohydrate-Derived Polyamides. Trends in Polym. Sci., 1996, vol. 4, pp. 249-252.

30. Lee H., Medsire E., Cohen R.E., Rubner M.F. Strategies for Hydrogen Bonding Based on Layer-byLayer Assembly of Poly(Vinyl Alcohol) With Weak Polyacids. Macromolecules, 2012, vol. 45, pp. 347-355.

31. Lozinskiy V.I., Damshkaln L.G., Bloch K.O., Vardi P., Grinberg N.V., Burova T.V., Grinberg V.Ya. Application of Poly(vinyl alcohol) Cryogels in Biotechnology. J. Appl. Polym. Sci., 2008, vol. 108, pp. 3046-3062.

32. Lozinskiy V.I., Damshkaln L.G., Kurochkin I.N., Kurochkin I.I. The Study of Cryostructuration of Polymer Systems. Colloid J., 2008, vol. 70, pp. 189-198.

33. Lozinskiy V.I., Damshkaln L.G., Kurochkin I.N., Kurochkin I.I. The Influence of 
Surfactants on the Properties and Structure of GasFilled (Foamed) Poly(vinyl alcohol) Cryogels. Colloid J., 2005, vol. 67, pp. 589-601.

34. Lozinskiy V.I., Damshkaln L.G., Shaskolskiy B.L., Babushkina T.A., Kurochkin I.N., Kurochkin I.I. Poly(Vinyl Alcohol) Composite Cryogels Filled With Microparticles of Polymer Dispersion. Colloid J., 2007, vol. 69, pp. 747-764.

35. Lozinskiy V.I., Domotenko L.V., Zubov A.L., Simenel I.A. The Study of Ciyostructuration of Polymer System. J. Appl. Polym. Sci., 1996, vol. 61, pp. 1991-1998.

36. Lozinskiy V.I., Galaev I.Y., Plieva F.M., Savina I.N., Jungvid H., Mattiasson B. Polymeric Cryogels as Promising Materials of Biotechnological Interest. Trends in Biotechnology, 2003, vol. 21, pp. 445-451.

37. Lozinskiy V.I., Morozova S.A., Vainerman E.S., Titova E.F., Shtilman M.I., Belavtseva E.M., Rogozhin S.V. Characteristic Features of the Formation of Crosslinked Poly(acryl amide) Cryogels Under Different Thermal Conditions. Acta Polymerica, 1989, vol. 40, pp. 8-15.

38. Lozinskiy V.I., Plieva F.M. Poly(vinyl alcohol) Cryogels Employed as Matrices for Cell Immobilization. Enzyme Microb. Technol., 1998, vol. 23, pp. 227-242.

39. Lozinskiy V.I., Plieva F.M., Galaev I.Yu., Mattiasson B. Poly(vinyl alcohol) Cryogels Employed as Matrices for Cell Immobilization. Bioseparation, 2001, vol. 10, pp. 163-188.

40. Lozinskiy V.I. Polymeric Cryogels as a New Family of Macroporous and Supermacroporous Materials For Biotechnological Purposes. Russ. Chem. Bull., 2008, vol. 57, pp. 1015-1032.

41. Lozinskiy V.I. Cryotropic Gelation of Poly(vinyl alcohol) Solutions. Russian Chem. Revs., 1998, vol. 67, pp. 573-586.

42. Lozinskiy V.I. Cryogels on the Basis of Natural and Synthetic Polymers: Preparation, Properties and Application. Russian Chem. Revs., 2002, vol. 71, pp. 489-511.

43. Lozinskiy V.I., Sakhno N.G., Damshkaln L.G., Bakeeva I.V., Zubov V.P., Kurochkin I.N., Kurochkin I.I. Physicochemical Properties of Poly(vinyl alcohol) Cryogels and Specific Features of Their Macroporous Morphology. Colloid J., 2011, vol. 73, pp. 225-234.

44. Lozinskiy V.I., Solodova E.V., Zubov A.L., Simenel I.A. Structural Changes Accompanying the Isothermal Gelation of Polyacrylonitrile Solutions. J. Appl. Polym. Sci., 1995, vol. 58, pp. 171-178.

45. Lozinskiy V.I., Vainerman E.S., Domotenko L.V., Blumenfeld A.L., Rogov V.V., Barkovskaya E.N., Fedin E.I., Rogozhin S.V. Characteristic Features of the Freezing of Concentrated Aqueous Poly(vinyl alcohol) Solutions. Colloid J. USSR, 1989, vol. 51, pp. 592-596. (in Russian).
46. Lozinskiy V.I., Vainerman E.S., Domotenko L.V., Mamtsis A.M., Titova E.F., Belavtseva E.M., Rogozhin S.V. Poly(vinyl alcohol) Cryogels Employed as Matrices for Cell Immobilization. Colloid Polym. Sci., 1986, vol. 264, pp. 19-24.

47. Lozinskiy V.I., Vakula A.V., Zubov A.L. Swelling Behavior of Poly(vinyl alcohol) Cryogels. Soviet Biotechnology, 1992, no. 4, pp. 1-11.

48. Lozinskiy V.I., Damshkaln L.G. Study of Cryostructuration of Polymer Systems. Foamed Poly(vinyl alcohol) Cryogels. J. Appl. Polym. Sci., 2001, vol. 82, pp. 1609-1619.

49. Markvicheva E.A., Lozinskiy V.I., Plieva F.M., Kochetkov K.A., Rumsh L.D., Zubov V.P., Maity J., Kumar R., Parmar V., Belokon Yu.N. GelImmobilized Enzymes as Promising Biocatalysts for Enantioselective Hydrolysis in Water/Organic Media. Pure and Appl. Chem., 2005, vol. 77, pp. 227-236.

50. Mathews D.T., Birney Y.A., Cahill P.A., McGuinness C.B. Mechanical and Morphological Characteristics of Poly(vinyl alcohol)/Chitosan Hydrogels. J. Appl. Polym. Sci., 2008, vol. 109, pp. 1129-1137.

51. Moayedi1 H., Asadi A., Moayedi F., Huat B.K. Zeta Potential of Tropical Soil in Presence of Polyvinyl Alcohol. Int. J. Electrochem. Sci., 2011, no. 6, pp. 1294-1306.

52. Nambu M. Rubber-Like Poly(vinyl alcohol) Gel. Kobunshi Ronbunshu, 1990, vol. 47, pp. 695-703. (in Japanese).

53. Nikonorov V.V., Ivanov R.V., Kildeeva N.R., Bulatnikova L.N., Lozinskiy V.I. Cryotropic Gelation of Ovalbumin Solutions. Polymer Sci., 2010, vol. 52, pp. 828-834.

54. Nikonorov V.V., Ivanov R.V., Kildeeva N.R., Lozinskiy V.I. Effect of Polymer-Precursor Molecular MASS on the Formation and Properties of Covalently Crosslinked Chitosan Cryogels. Polymer Sci., 2011, vol. 53, pp. 1150-1158.

55. Nugent M.J.D., Higginbotham C.L. Preparation of a Novel Freeze Thawed Poly(vinyl alcohol) Composite Hydrogel for Drug Delivery Application. Eur. J. Pharm. Biopharm., 2007, vol. 67, pp. 377-386.

56. Peppas N.A., Stauffer Sh.R. Reinforced Uncrosslinked Poly(vinyl alcohol) Gels Produced by Cyclic Freezing-Thawing Processes: A Short Review. J. Contr. Release, 1991, vol. 16, pp. 305-310.

57. Plieva F.M., Galaev I.Yu., Noppe W., Mattiasson B. Cryogel Applications in Microbiology. Trends in Microbiol., 2008, vol. 16, pp. 543-551.

58. Plieva F.M., Karlsson M., Anguilar M.-R., Gomez D., Mikhalovsky S., Galaev I.Y. Pore Structure in Supermacroporous Polyacrylamide-Based Cryogels. Soft Matter, 2005, no. 1, pp. 303-309.

59. Polyakov V.I., Grinberg V.Ya., Tolstoguzov V.B. Application of Phase Diagram of Water- 
Casein-Soybean Globulin. Polym. Bull., 1980, no. 2, pp. 757-760.

60. Ricciardi R., Auriemma F., Rosa C.D., Laupretre F. Structural Changes Induced by Thermal Treatments on Emptied and Filled Clathrates of Syndiotactic Polystyrene. Macromolecules, 2004, vol. 37, pp. 1921-1927.

61. Ricciardi R., Gaillet C., Ducouret G., Lafuma F., Laupretre F. Poly(vinyl alcohol) (PVA) Is a WaterSoluble, Biocompatible and Biodegradable Polymer, Which Has Been Widely Applied in Biomedical Fields. Polymer, 2003, vol. 44, pp. 3375-3380.

62. Savina I.N., Lozinskiy V.I. Cryogels Filled With Dispersed Particles Containing Ionogenic Groups. Colloid J., 2004, vol. 66, pp. 343-349.

63. Sergeev G.B., Batyuk V.A. Reactions in Frozen Multicomponent Systems. Russ. Chem. Rev., 1976, vol. 45, pp. 391-423.

64. Sheldon R.A. Enzyme Immobilization: The Quest for Optimum Performance. Adv. Synth. Catal., 2007, vol. 349, pp. 1289-1307.

65. Shoichet M.S. Polymer Scaffolds for Biomaterials Applications Molly. Macromolecules, 2010, vol. 43, pp. 581-591.

66. Suri A., Campos R., Rackus D.R., Spiller N.J.S., Richardson C., Palsson L.O, Kataky R. Liposome-Doped Hydrogel for Implantable Tissue. Soft Matter, 2011, no. 7, pp. 7071-7077.

67. Surry K.J.M., Austin H.J.B., Fenster A., Peters T.M. Poly(vinyl alcohol) Cryogel Phantoms for Use in Ultrasound and MR Imaging. Phys. Med. Biol., 2004, vol. 49, pp. 5529-5546.

68. Suzuki M., Hirasa O. An Approach to Articial Muscle Using Polymer Gels Formed by Microphase Separation. Adv. Polym. Sci., 1993, vol. 110, pp. 241-261.

69. Trieu H.H., Qutubuddin S. Poly(vinyl alcohol) Hydrogels. Colloid Polym. Sci., 1994, vol. 272, no. 8, pp. 301-309.

70. Trieu H. Qutubuddin S. Poly(vinyl alcohol) Hydrogels: Effects of Processing Parameters on Structure and Properties. Polymer, 1995, vol. 36, pp. 2531-2539.
71. Tsunemoto N., Suzuki M. Friction Between Polymer Networks of Gelsand Solvent. Polymer Gels and Networks, 1994, no. 2, pp. 247-255.

72. Valentín J.L., Lypez D., Hernández R., Mijangos C., Saalwächter K. Structure of Poly(vinyl alcohol) CryoHydrogels as Studied by Proton Low-Field NMR Spectroscopy. Macromolecules, 2009, vol. 42, pp. 263-272.

73. Varfolomeev S.D., Rainina E.I., Lozinskiy V.I. Cryoimmobilized enzymes and cells in organic synthesis. Pure \& Appl. Chem., 1992, vol. 64, pp. 1193-1196.

74. Wan W.K., Campbell G., Zhang Z.F., Hui A.J., Boughner D.R. Osteogenic Differentiation of Mouse Adipose-Derived Adult Stromal Cells Requires Retinoic Acid and Bone Morphogenetic. J. Biomed. Mater. Res., 2002, vol. 63, pp. 854-861.

75. Watase M., Nishinari K., Nambu M. Anomalous Increase of the Elastic Modulus of Frozen Poly (Vinyl Alcohol) gels. Cryo-Letters, 1983, no. 4, pp. 197-200.

76. Willcox P.J., Howie D.W., Schimdt-Rohr K., Hoagland D.A., Gido S.P., Pudjijanto S., Kleiner L.W., Venkatraman S. Microstructure of Poly(vinyl alcohol) Hydrogels Produced by Freeze/Thaw Cycling. J. Polym. Sci., Polym. Phys., 1999, vol. 37, pp. 3438-3454.

77. Williams P.A., Phillips G.O. Handbook of Hydrocolloids. Cambridge, Woodhead Publ. Ltd., 2000. $168 \mathrm{p}$.

78. Yamaura K., Tanigami T., Hayashi N., Kosuda N., Okuda S., Takemura Y., Itoh M., Matsuzawa S. Preparation of High Modulus Poly(vinyl alcohol) by Drawing. J. Appl. Polym. Sci., 1990, vol. 40, pp. 905-916.

79. Yao K., Shen S., Yun J., Wang L., He X., Yu X. Preparation of Polyacrylamide-Based Supermacroporous Monolithic Cryogel Beds Under Freezing-Temperature Variation Conditions. Chem. Eng. Sci., 2006, vol. 61, pp. 6701-6708.

80. Yokoyama F., Masada I., Shimamura K., Ikawa T., Monobe K. Morphology and Structure of Highly Elastic Poly(Vinyl Alcohol) Hydrogel Prepared by Repeated Freezing and Melting. Colloid Polym. Sci., 1986, vol. 264, pp. 595-601.

81. Zeman L., Patterson D. Effect of the Solvent on Polymer Incompatibility in Solution. Macromolecules, 1972, no. 4, pp. 513-516.

\title{
ИСПОЛЬЗОВАНИЕ КОМБИНИРОВАННОГО МЕТОДА СЕПАРАЦИИ ДЛЯ ПОЛУЧЕНИЯ КРИОГЕЛЕЙ С ПОРИСТОЙ СТРУКТУРОЙ
}

\author{
Владимир Иосифович Лозинский
}

\author{
Доктор химических наук, профессор, \\ заведующий лабораторией криохимии (био)полимеров, \\ Институт элементоорганических соединений им. А. Н. Несмеянова РАН \\ loz@ineos.ac.ru \\ ул. Вавилова, 28, 119991 г. Москва, Российская Федерация
}




\section{Юрий Алексеевич Антонов}

Доктор биологических наук, профессор, научный сотрудник, Институт биохимической физики им. Н. М. Эмануэля РАН chembio@sky.chph.ras.ru ул. Косыгина, 4, 119334 г. Москва, Российская Федерация

\section{Лилия Григорьевна Дамшкалн}

Научный сотрудник,

Институт биохимической физики им. Н. М. Эмануэля РАН

chembio@sky.chph.ras.ru

ул. Косыгина, 4, 119334 г. Москва, Российская Федерация

\section{Мариам Григорьевна Езерницкая}

Кандидат химических наук, старший научный сотрудник, Институт элементоорганических соединений им. А. Н. Несмеянова РАН loz@ineos.ac.ru ул. Вавилова, 28, 119991 г. Москва, Российская Федерация

\section{Юлия Константиновна Глотова}

Научный сотрудник,

Институт биохимической физики им. Н. М. Эмануэля РАН

hembio@sky.chph.ras.ru

л. Косыгина, 4, 119334 г. Москва, Российская Федерация

Аннотация. Получены и исследованы криогели поливинилового спирта, при формировании которых охлаждение исходного раствора полимера (100 г/л) для его замораживания осуществляли со скоростью $1.85,0.3,0.03$ или $0.003{ }^{\circ} \mathrm{C} /$ мин, а нагревание замороженных $\left(20^{\circ} \mathrm{C} / 12\right.$ ч) препаратов при их оттаивании - со скоростью $0.3,0.03$ или $0.003{ }^{\circ} \mathrm{C} /$ мин. Показано, что заметное влияние скорости охлаждения на жесткость и теплостойкость гелевой матрицы проявляется при переходе к очень медленным режимам охлаждения (порядка тысячных ${ }^{\circ} \mathrm{C} /$ мин). Одной из причин снижения жесткости, а также энтальпии плавления узлов надмолекулярной сетки получающихся криогелей является образование однофазного гидрогеля при продолжительном пребывании концентрированного раствора полимера в зоне пониженных температур еще до начала кристаллизации льда. Влияние режима охлаждения замораживаемого раствора полимера на пористую структуру образующихся после оттаивания криогелей имеет неоднозначный характер, поскольку является многофакторным, и поэтому во многих случаях четкие корреляции «структура - свойство» не наблюдаются.

Ключевые слова: поли(виниловый спирт), гуммиарабик, жидкая фаза сепарации, процесс замораживания-оттаивания, криогели с пористой структурой. 